\title{
Félix Rodríguez González* and Sebastian Knospe The variation of calques in European languages, with particular reference to Spanish and German: Main patterns and trends
}

https://doi.org/10.1515/flin-2019-2009

Submitted March 21, 2017; Revision invited February 14, 2018;

Revision received August 22, 2018; Accepted September 28, 2018

Abstract: This article compares the use of calques modelled on anglicisms in different European languages, especially Spanish and German, which do not only show structural differences (e.g. with regard to the use of noun-noun compounds, which are more common in German) but also reflect different attitudes towards English. Aspects covered range from the factors generally favouring the coinage of such replacive forms, to the reasons for the emergence of different types of calques, to variations in their use and challenges concerning their identification. To unravel the main patterns and trends in calquing, this study includes numerous examples from written and oral language, i.e. items of different register affiliation, age, length, and semantic transparency. On a theoretical level, the article incorporates findings from the fields of lexicology, contact linguistics and sociolinguistics.

Keywords: calques, Spanish, German, borrowing, contact linguistics, lexis

\section{Introduction}

Language contact is a multifaceted phenomenon which, because of the massive mobility and rapid social as well as cultural developments of our times, has gained major attention in linguistic research. Typically, studies on language mixing focus on cases involving the overt use of non-native material. To provide an analysis of the full range of contact-induced innovations, it is, however, necessary to go beyond this. Hence, this article is centered on

\footnotetext{
*Corresponding author: Félix Rodríguez González, University of Alicante, Alicante, Spain, E-mail: frodriguez@ua.es

Sebastian Knospe, University of Greifswald, Greifswald, Germany,

E-mail: sebastian_knospe@web.de
} 
a phenomenon that has been part and parcel of classical models on linguistic borrowing (Betz 1949; Haugen 1950; Weinreich 1953: 47-53) but later on faced a loss of interest: calques. Taking a qualitative and largely synchronic perspective, we seek to shed light on the systematics of calquing by comparing the situation in different European languages. In particular, the motivations behind and variations in calquing are analyzed. First, the article identifies the factors that generally pave the way for calques, summarizing the conditions under which they tend to become established. Second, there is a discussion of what may bring about varying forms of calques. Third, we explore the challenges that may be linked to the identification of calques. The conclusion provides a summary and lists some desiderata for future research.

\section{Calques from a cross-linguistic perspective}

Before further specifying the agenda of this article, we will briefly characterize the phenomenon under scrutiny and relate it to other products of language contact. In a nutshell, a calque occurs when a loan element does not appear in its integral form in a receiving language, but is replaced by a native term (Thomason 2001: 260). Seen from this angle, it represents a conceptual replica - or its close approximation - of the model sign found in the donor language (Onysko 2007: 21-34). In other words, speakers who produce a calque or 'loanshift' (Haugen 1950) do not adopt the material side of the foreign sign but, following Johanson (2002: 8-18), rather selectively 'copy' its semantic and often also its structural or combinational properties. Similar to Johanson (2002), who treats calques as 'semantic' or 'semantic-combinational copies' of donor-language signs, Matras and Sakel (2007) regard them as outcomes of a mode of 'pattern replication' which they oppose to instances of 'matter replication'. All these labels, used by many authors to depict calques, imply that they are camouflaged results of borrowing or transfer that do not stand out through formal markers of foreignness. Native onsurface, they may be hard to discern empirically. Amongst others, it is for this reason that research has devoted comparatively less attention to the study of calques than to the investigation of loanwords. Thinking of linguistic imports from the English language, the concept of 'anglicism' is therefore usually employed today as an umbrella term for all items that look English because of the foreigness they show in spelling, pronunciation and/or morphology (cf. Görlach 2003; Onysko 2007; Furiassi etal. 2012; Knospe 2014). Scholars adopting this 
definition commonly foreground the following three phenomena, illustrated below with examples from Spanish (Sp.) and German (Ge.) ${ }^{1}$ :

a) Simple or compound loanwords, which may be adapted to varying degrees on different linguistic levels, i.e. phonemically, orthographically, morphologically, and/or semantically, ${ }^{2}$ as illustrated by Sp. dealer (or díler), groggy (or grogui), disc jockey (disyoquei. DJ or deejay) and Ge. Dealer, Discjockey (Diskjockey, also abbreviated as DJ); additionally, phrasal loans such as American way of life and last but not least are possible and documented in both languages.

b) Hybrid formations or loanblends, i.e. combinations of borrowed and native lexical items, e.g. Sp. crema aftershave/Ge. Aftershave-Balsam.

c) Pseudo-loans, of English material, but non-existent in this form and/or meaning in L1 English, ${ }^{3}$ prominent examples are Ge. handy 'mobile phone, cell phone' and Sp. busman 'bus conductor'.

As the phenomena under (a) to (c) show a conspicuous English form (which may, of course, diminish through processes of formal integration), it does not come as a surprise that examples from these three categories are named most often when speakers of, say, German or Spanish are asked about their awareness of the current impact of English in their languages. Although calques fall out of sight then, it makes sense not to exclude them altogether, as they can be connected to anglicisms proper in different form. For instance, hybrids may go back to a translation of one part of a complex English expression, which leads to the production of 'semi-calques'. Alternatively, hybrids may spring from a free combination of a loanword with a native element - two cases which are not easy

1 This is the list of codes assigned for the languages cited in the article: Alb. (Albanian), Bul. (Bulgarian), Cr. (Croatian), Dut. (Dutch), Est. (Estonian), En. (English), Fr. (French), Ge. (German), Gr. (Greek), Hun. (Hungarian), Ice. (Icelandic), It. (Italian), Lat. (Latin), Nor. (Norwegian), Pol. (Polish), Por. (Portuguese), Ro. (Romanian), Rus. (Russian), Sr. (Serbian), Ukr. (Ukrainian), Wel. (Welsh).

2 The formal adaptation (or integration) of loanwords and phrasal loans is a complex process which is determined by two dimensions of conformity: conformity with the system of the donor language and conformity with the system of the recipient language. Importantly, the moment a loanword enters, say, German or Spanish, it may conform to the rules of the recipient language on a specific linguistic level (e.g. orthography) but not on others because the pronunciation and morphology of the source language form may not match those of the recipient language. In the latter case, formal adaptations increasing conformity with the system of the recipient language may follow. For a detailed discussion of the mechanisms involved, see Winter-Froemel (2011: 63-109).

3 For studies of this, see Cypionka (1994), Humbley (2008), Furiassi (2010), Rodríguez González (2013), and Furiassi and Gottlieb (2015). 
if not completely impossible to keep apart in practice (Duckworth 1970: 15; Carstensen and Busse 1993-1996: 68). For this and other reasons, scholars like Gottlieb (2005: 163) adopt a wide definition of the term anglicism which goes beyond the phenomena listed under (a)-(c), including “[...] any individual or systemic language feature adapted or adopted from English, or inspired or boosted by English models, used in intralingual communication in a language other than English." ${ }^{4}$ As we will see, camouflaged types of borrowing are just as multi-faceted as loanwords. In addition, they may bring about structural innovations in the receiving language, for instance on the levels of word-formation or word order (Picone 1996; Gottlieb 2004, 2005; Mailhammer 2008). Another argument for studying loanshifts is that they often compete with English loanwords in the receiving language (cf. Winter-Froemel et al. 2014).

One reason for comparing calques in different European languages is that the Romance and Germanic languages show major typological divergences. While German and English share a number of cognates, the situation is more differentiated for English and French: English has borrowed extensively from French but changed the form and/or the meaning of the items so that false cognates represent a problem area of study today. ${ }^{5}$ It is true that French borrowings also entered German in a considerable number but they were less semantically changed. ${ }^{6}$ Another difference between the Romance and Germanic languages can be found on the grammatical level: e.g. English and German share the pre-modifying position of noun-qualifying adjectives, whereas the

\footnotetext{
4 Apart from the lexical, phraseological and semantic levels, "language features adapted or adopted from English" (Gottlieb 2005: 163) may also be found in pronunciation, spelling, morphology and syntax - aspects not covered in this article. For a comprehensive overview see Gómez Capuz (1997) and Gottlieb (2004, 2005). Picone (1996) also has a broad definition of the term 'Anglicism' and includes aspects related to pronunciation, spelling, morphology and syntax. When it comes to spelling, however, he also notes that in the domain of advertising in particular, which is where spelling alterations are the most pervasive, orthographic streamlining is often considered felicitous (e.g. rapide $>$ rapid) and that this can overlap with apparent anglicization.

5 However, it would be mistaken to assume that all French loans have undergone significant formal changes in English. For instance, in many cases borrowings from Anglo-Norman French retain, in contemporary English, some of the original pronunciation features present at the time of the borrowing. Affricates provide a good example here: challenge, chandler, jet, judge, etc. (Indeed, the de-affricated pronunciation in Modern French evolved later). We also need to be aware of a shared 'Euro-Latin' heritage as German, French, Spanish and other languages productively used (and still use) Latin and Greek elements to form new words (on Euro-Latin see Munske and Kirkness 1996).

6 For a discussion of language contact between English, French and German and its reflections in historical and present-day word-formation see, e.g. Dietz (2002), Lutz (2002) as well as Leisi and Mair (2008: 41-58) and Durkin (2014: 223-423).
} 
Romance languages usually place adjectives after nouns. As a rule, structural similarities lower the threshold for some types of borrowing while the opposite trend holds for situations where there are numerous structural divergences between the donor and the recipient languages (Leisi and Mair 2008: 36-40; Knospe 2014: 51-112).

Looking beyond the structural level, we might also cite sociolinguistic reasons for a comparison of the two receiving languages focused on here. One of them has to do with the fact that the respective language cultures, partly as a result of different language policies, are known for different degrees of openness towards English. Indeed, present-day German exhibits a generally welcoming attitude towards anglicisms. After all, the Germans have not implemented any measures of institutional language intervention on the national level although there are some smaller, privately run initiatives that raise their voices against the seemingly excessive use of English in some communicative domains (cf. Pfalzgraf 2009 on the history of purism in Germany and Section 2 of this article). By contrast, most Romance languages show a much higher degree of purism, and France is known for a more rigid language policy (cf. Adamson 2007), although, when it comes to anglicisms, there is a wide divergence between official government policy and actual practice, especially in the digital age. Without ignoring the complex factors impinging on language use, these differences in language policies have an impact on the question of whether borrowings proper or calques may win out in authentic language use, or whether they are employed side by side. Yet, there are also factors which are valid across language boundaries, at least for the languages under consideration here as far as this can be derived from the representative data set we use.

The data in this article stem from two sources: first, dictionaries of anglicisms as indicated in the bibliography section, above all DEA (Görlach 2002) and, specifically for Spanish, GDA (Rodríguez González 2017). Second, Google searches limited to German and Spanish were carried out to verify the $D E A$ entries. For German the reference corpus COSMAS II served as an additional source to compensate for the non-existence of a newer dictionary of anglicisms.

Before embarking on the directions of research outlined above, a few additional remarks on terminology are necessary. Calques will be understood here as lexical or phrasal items with a certain degree of use and acceptance among speakers of the receiving languages, a fact which was ascertained by consulting the aforementioned sources. However, it needs to be stressed that it is also possible for borrowings to be substituted by ad hoc calques, which then have the status of nonce creations. They often emerge in bilingual speech and may or may not become established. The option of ad hoc calques is only briefly considered here (cf. Backus and Dorleijn 2009; Lipski 2008; Meriläinen et al. 2016). 
By calques, we refer mainly to the lexical-semantic sphere. Our approach differs from that of some scholars who also plead for the inclusion of more abstract (grammatical) transfer features under this label (Tóth 2007: 115-117; Backus and Dorleijn 2009; Meriläinen et al. 2016). As a result, we will not go into the interesting issue of 'syntactic calques' or 'syntactic anglicisms' as they are often labeled, based on a wide definition of the term 'anglicism'. Examples illustrating this process of calquing are, for instance, found in the language of the descendants of German settlers in Australia and other parts of the world, e.g. für Examen sitzen < to sit for exams instead of Standard German Examen machen/schreiben (Clyne 2003: 145). Illustrative Spanish examples cited by Pratt (1980: 209-211) are no le había visto por un año < I have not seen him for a year instead of no le había visto desde hacía un año and jugar tenis < play tennis instead of jugar al tenis.

As to the systematics for grouping calques, we follow Betz's influential (1949) typology, which has been widely discussed and applied in the literature on borrowing. Thus, we differentiate between four subtypes of calques. Note that Haugen (1950) excludes the third category from his taxonomy:

a) loan translations, which are based on a literal translation of every component of a complex, i.e. usually a compounded English sign, e.g. Sp. tarjeta de crédito/Ge. Kreditkarte<credit card; Sp. (de) alta tecnología/Ge. Hochtechnologie, Spitzentechnologie < high-tech(nology);

b) loan renderings (also called 'loan renditions'), which deviate from the meaning and/or morphology of the English source by translating it more freely, e.g. Sp. hombre hecho a sí mismo < self-made man, derechos de autor < copyright; Ge. Unternehmensforschung < operations research, Wechselwähler < floating voter;

c) loan creations such as Sp. telenovela or culebrón (lit. 'long snake', because of its convoluted plot)<soap opera and Sp. huelga de celo<go-slow; Ge. Klimaanlage < air-conditioning and Ge. Luftkissenboot< hovercraft, or Fr. ordinateur < computer; these are free equivalents formally independent from the patterns of the source language;

d) semantic calques of the type viajar for trip in Sp. drug slang or Ge. Maus for the computer gadget (<mouse); in this case, speakers impose an additional (metaphorical) meaning on an existing sign in the receiving language, orienting themselves towards an English model sign (as a consequence, Sp. viajar and Ge. Maus have become polysemous as in English, standing for a journey and a psychedelic experience, or a rodent and a computer mouse, respectively).

Similar to the position taken here, Winter-Froemel (2008) regards loan translations and loan renderings as alternatives to loanwords proper, which she describes as 'analogical innovations' as they are conceptually (and structurally) 
modelled on the donor language sign, albeit with degrees of exactness (also cf. Jansen 2005: 44-49, 124-125). Simultaneously, she treats loan creations as a separate (i.e. third) typological scenario given that they are structurally independent innovations' coined by speakers of the recipient language. However, the criteria she uses to compare the different forms of borrowing do not deny the general validity of categories (a) to (d).

Having clarified the typological base of our analysis, a few short notes on our methodology should be added. As already suggested, our main attempt is to show the typical mechanisms behind the formation of replacive forms. To illustrate the systematics of calquing, we employ an array of words and phrases documented in different European languages. In this respect, two concepts have to be stressed:

First, we need to be aware of a methodological problem inherent to all investigations on the topic since it is not possible to detect the reasons that make speakers prefer calques over anglicisms proper with absolute certainty. Inevitably, our interpretations may contain a certain degree of subjectiveness (for other issues regarding identification of calques, see Section 6 of this article). Second, it is worth reminding that all lexical innovations, including calques, are actualized in communicative performance. To capture the latter, it does not suffice to adopt a lexicological or lexical-semantic approach even though such a framework is indispensable for a detailed description of individual lexical items. Rather, the lexicological framework needs to be open to insights from contact linguistics and sociolinguistics. A complex approach that lends itself to being applied here is Matras (2009: 4-6), who assumes that speakers, in settings of language contact, weigh different linguistic options and their social consequences when opting for the use of a borrowed item against that of an existing sense-related native word or calque. In planning their speech (or writing), they, as communicative agents, pay attention to context-bound norms, e.g. specific requirements of their addressees, who may be less fluent in English. ${ }^{7}$ Yet, they often wish to exploit the full expressive potential of their repertoire. Accordingly, all linguistic choices are situated in a field of tension, and modelling it may help us to interpret the various trends at play in an integrative manner. What is more, Matras' approach may be widened so as to include cognitive linguistic factors, which may be informative as well since linguistic units of different form and provenance may have different degrees of salience. Also, Matras' model is dynamic in that it acknowledges the constant flux in the vocabulary stock and potential changes in the status of individual linguistic entities.

7 Similar to Matras' (2009) approach, Myers-Scotton (1995) assumes that codeswitching is based on rational choices of the bilingual speakers concerned. 


\section{Factors promoting the formation of calques}

Following the agenda sketched in the introduction, let us first delve into the factors that promote the coinage and establishment of calques, in particular that of loan translations. Grosso modo it can be claimed that the motives responsible for their emergence are opposite to the ones which make speakers resort to loanwords proper (cf. Rodríguez González 1996). ${ }^{8}$

There are two main categories of factors which may make language users create and adopt replacing terms for anglicisms. One set of factors has to do with the linguistic (morphological and semantic) characteristics of the borrowing vis$\grave{a}$-vis the calque; these can be described as linguistic, or even more precisely, as intralinguistic parameters. Another set of factors is concerned with specific extralinguistic motives and conditions accompanying the coinage of native terms. The latter level will be addressed first. Importantly, several of the factors mentioned in this section may compete with each other. Yet, they are not necessarily mutually exclusive but may also overlap. Refined statistical methods would be required to test the impact of different factors, but, for the purposes of this article, a qualitative description must suffice.

\subsection{Extralinguistic motives and conditioning factors}

In situations where anglicisms, especially prestigious lexemes that occur in specialized discourse, remain undecodable for a specific target group, calques are a plausible option (cf. Dubey 1991: 22; Bader 1994: 98). Their coinage may be driven by the wish to preserve the native tongue and by egalitarian conceptions of language and communication. German especially attests to the work of language purists, such as von Zesen, Campe, and Harsdörffer, whose proposals have sometimes had significant repercussions on general use, contributing to the adoption of replacements for Latin and French, but also for English expressions. Dunger $(1899,1909)$ was an eminent German figure fighting against what he and others felt to be a real 'Anglomania' at the late nineteenth and early twentieth century. He largely objected to the use of anglicisms in fields related to social and public affairs, clothing and sports. As Busse and Görlach (2002: 16)

8 In this respect, loan creations behave differently, as argued by Jansen (2005: 43-49, 124-125) and Winter-Froemel (2008). As 'independent innovations' of the recipient language (WinterFroemel 2008), which are only conceptually but not structurally modelled on the donor language, they are often coined highly consciously. This mainly ties in with the extralinguistic factors described in Sections 3.1.1. and 3.1.2. 
point out, he appended "lists of some 165 English tennis terms and 84 football expressions with German equivalents; the latter were [...] made available in post form for display in tennis and football clubs asking members to use German terms exclusively". This turned out to be a highly successful endeavour, as most suggestions for German football terms are standard up to the present day, albeit less so in Austria and German-speaking Switzerland (cf. Rash 1994; Muhr 2002). As for Spain, the articles by Madariaga (1962, 1966), who strongly condemned the overuse of English loanwords, and Alfaro's first dictionary of anglicisms (Alfaro 1970 [1964]), are the best exponents of this view. Even though they proposed calques as well, their proposals did not have effects similar to the ones just mentioned for German.

Occasionally, calques are also formed for humorous purposes in order to cause surprise and amusement. ${ }^{9}$ The coiner, then, does not intend to propose the item as a durable replacement for the respective loanword. This may, for instance, be the case in a comic strip where the Spanish initials PMI 'persona muy importante' are used instead of the English form VIP 'very important person'. A similar intention might be assumed for gentece 'gente que tiene once, doce, trece, catorce, quince años' [twelve, thirteen, fourteen, fifteen years], a creation induced by its analogy with teenager 'adolescent aged between thirteen and nineteen', but not known in general use. The same goes for the jocular depiction of a joystick as a legendärer Luststab (lit. 'legendary joy stick') in a sales advertisement posted on the German website markt.de in September 2016. Clearly, the marketer uses a literal translation technique here, replacing En. joy for Ge. Lust and En. stick for Ge. Stab. Obviously, this is supposed to emphasize the fun factor in computer games, but it is also clearly intended to convey sexual innuendo.

Even if the external (sociolinguistic) conditions are otherwise in favour of calques, they may fail to be accepted. In that case, the aforementioned factors are overridden or cancelled out by other, usually internal linguistic factors, provided these are strong enough. To make the interplay of these extralinguistic and intralinguistic parameters visible, some elaboration on this aspect will follow before we specify extralinguistic factors. One possibility is that the intended increase in clarity through a calque, which is a subjective and thus problematic notion, may not be recognized by other language users. In fact, there are many historical examples of native surrogate terms that were felt to be

\footnotetext{
9 Amusement may also be intended in other cases, e.g. when the habitual orthography of anglicisms is deformed. Consider, for instance, the humoristic spelling Mehl for (e-)mail in German, playing with the phonemic overlap of En. mail and Ge. Mehl 'flour' (see WinterFroemel 2011: 439-466).
} 
infelicitous. As a consequence, some of them have caused ridicule and, despite a purist Zeitgeist, not been taken up. For instance, an infamous proposal to replace the German noun Nase 'nose', which goes back to Lat. nasus, was the compound Gesichtserker, lit. 'face oriel', which was mentioned in a letter by the author Friedrich von Matthisson (1825 [1793]: 363). In contemporary sports vocabulary we may name the French translation balle au pied for football, which is less common than language purists might wish for. Probably it did not catch on in general use in the face of a more international term, which is important in a globally successful sport.

Additionally, calques may not reach the same level of acceptance as the respective loanwords they are supposed to replace if they are seen as semantically less precise or if they are differently connoted than the latter. Looking at the suggestions of the Verein Deutsche Sprache (VDS, German Language Association), which, as a language-watching NGO, has compiled an 'Anglicism Index', ${ }^{10}$ one is surprised to find Kind 'child' and Göre 'brat' among the suggested surrogates for the anglicism Kid. In most contexts - and context always matters -, these proposals would not represent adequate alternatives for the English loanword. On the one hand, Ge. Kind constitutes a default term, which refers to children irrespective of their age but does not convey the idea of coolness or trendiness commonly evoked by Kid. On the other hand, Göre is only regionally used and carries pejorative overtones. Similarly, the prescribed use of replacive forms for anglicisms in the Federal Ministry of Transport during the term of office of Peter Ramsauer partly became a target of public mockery. ${ }^{11}$ In fact, proposals such as the idea to replace Mailbox by elektronischer Postkasten (lit. 'electronic postbox' or Flipchart by either Tafelschreibblock (lit. 'notepad pinned onto a board' or Schreibblocktafel 'notepad board' may be seen as both morphologically too complex and semantically inadequate. Also Mailbox in German usually designates the place where incoming (mobile) phone messages are digitally stored. The use of the German adjective elektronisch, however, suggests a different meaning which is less wide-spread in German, referring to the storage system for e-mails. For another thing, the replacive forms Tafelschreibblock and its reverse, Schreibblocktafel, are suboptimal solutions because notepads are smaller than flipcharts and can be easily transported.

Even in cases where a translation proposed for an anglicism does not create a visible meaning difference, the inclination to use a specific calque may be low if the loanword dominates in the use of the media or in social networks whose

10 See Verein Deutsche Sprache (2016).

11 See Rheinische Post Online (2010). 
standard or substandard norms speakers identify with. This 'well-tread path effect' is particularly conspicuous in popular entertainment culture. While some speakers might still prefer to use the calque polo acuático in Spanish, the standard term used in the media is waterpolo. The same holds for beisbol (<baseball), fútbol (<football) or voleibol (<volleyball) which are generally favoured instead of the native equivalents pelota base, balompié, or balonvolea. (By comparison, German only has the anglicism Basketball; the term Korbball designates a game with quite different rules although the English word basket matches the German noun Korb.)

Finally, the substitution of loanwords by calques may be impeded if the former are seen as identity markers of a group, e.g. in youth slang, or if the replacement strategy would undermine euphemistic needs, i.e. the goal to avoid (native) taboo words as in the field of sexuality.

If, by contrast, these intralinguistic factors stay in the background while the aim to find a native equivalent dominates because of particular (macro-)sociolinguistic and attitudinal conditions, calques may be preferred. These external conditions will now be discussed further.

\subsubsection{Linguistic nationalism}

In some countries, nationalism is a factor which enhances support for native terms, including calques. Well-known examples in this respect are Iceland and France, which have established terminology commitees that are supposed to find native terms to replace foreign expressions (cf. Adamson 2007). Since these are obligatory in institutional use, some of the French anglicisms recorded in DEA carry the label 'ban' (=banned). Beyond the public sector, this policy is not necessarily followed, however, as the Loi Toubon and other language laws are not binding for private users. Still, the spirit remains and may account for some of the differences in the reaction towards anglicisms that are taken by speakers of French as opposed to those of other European languages. Thus, while in most European languages drive is a standard trm in tennis, the expression coup droit has become more frequent in French, due to the increase in popularity this sport has attained in France with players like Henri Leconte, Yannick Noah, Julie Halard and Mary Pierce, and several ATP and WTA tournaments. In other instances, French demonstrates a greater degree of autonomy by resorting to loan renderings where most of the other European languages have realized loan translations. According to $D E A$, this is, for example, the case with pacemaker which has been turned into Sp. marcapasos and Ge. (Herz-)Schrittmacher respectively, while French has followed a 
different path with stimulateur (cardiaque) 'cardiac stimulator'. Similarly, German, Spanish, and most other European languages have accepted the anglicism personal computer (PC). By contrast, though French initially adopted ordinateur personnel as well, the alternate terms micro(-ordinateur) and ordinateur individuel subsequently emerged.

The effects of nationalist language policies are most visible in times of dictatorship. For this Francoist Spain offers a clear example. After the civil war the Spanish government claimed control over the national vocabulary and targetted many English borrowings; amongst others, sandwich was replaced by emparedado and football by balompié (cf. Seco 1977: 200; Rodríguez González 2002a: 129-130). Also, the German Nazis had originally developed plans for banishing non-native expressions, but this policy was given up later on based on the insight that loanwords may also be (mis)used as rhetorical devices disguising the speakers' genuine intentions (cf. Busse and Görlach 2002: 16-17).

\subsubsection{Speakers lacking familiarity with the source language (English)}

Comparing the situation in different European languages, another factor to think of is the varying depth of influence of the English language in different countries (cf. Hoffmann 1996; De Houwer and Wilton 2011; Linn et al. 2015). As there is a longer tradition of teaching English and an overall more open attitude towards this language in the northern and western parts of the continent, speakers of the national European languages used there are usually more susceptible to anglicisms, whereas calques tend to be more wide-spread in eastern Europe according to DEA. For example, the phrase American way of life is typically represented by calques in Romanian, Russian, Bulgarian, and Greek, as the list reproduced below indicates: Ro. modul de viaţă American, Rus. amerikanskiǐ obraz zhizni, Bul. amerikanski nachin na zhivot, and Gr. amerikanikós trópos zoís.

In this example, Spanish takes a middle position because the forms modo/ estilo de vida americano alternate with the borrowing. However, the criterion 'lacking familiarity with the source language' must be taken with caution: after all, mobility and globalization continue to spread the English language. Arguably, the greater presence of English as a global phenomenon has a levelling effect on competence, since even indviduals who have not formally studied English have greater exposure to English vocabulary, resulting in, at the very least, a selective understanding of high-frequency vocabulary items. This could also reduce existing differences in the preference for calques or loanwords. 


\subsubsection{High-imposition interactions: translationese and situations of language shift}

Another set of factors can be subsumed under the term 'high-imposition interactions', known as the pragmatic motive that intervenes in a bilingual scenario (cf. Pütz and Neff van-Aerselaer 2008: 421). Initially shocking to critical language observers, traces of translationese may eventually become accepted by the general public. Often, the idiomatic level is affected. Here, we may face ritualized formulae that belong to the so-called 'repeated discourse' such as Ge. der frühe Vogel fängt den Wurm<the early bird catches the worm instead of the older German proverb wer zuerst kommt, mahlt zuerst, or the Spanish phrases olvídalo < forget it, déjame adivinarlo<let me guess, and damas y caballeros < ladies and gentlemen instead of the native señoras y señores (cf. Fiedler 2014; Gómez Capuz 2001).

The imposition of such translated structures onto the native tongue may come about unconsciously or be deemed adequate to keep lip synchrony in dubbed versions of films. Comparable linguistic phenomena are manifest in the speech of language users spending time in an Anglophone country for extended periods of time and thus (slowly) incorporating English forms even if the surface structures may look native. An interesting case is offered by foreign correspondents who work under constant time constraints. These conditions may induce moments in which native expressions are not available to them, resulting in frequent borrowing but also in enhanced uses of calques that might replace some native expressions. A striking example is the compound time bomb, traditionally rendered as bomba de relojeria and in the last few years occasionally replaced by the loan translation bomba de tiempo, as attested in most of the international newswires, especially those coming from the US.

Similarly, speakers may have relocated to an English-speaking area and gradually lose contact with their mother tongue and their former home country. This, in turn, initiates a gradual language shift (Winford 2003: 208-267), which ties in psycholinguistically with processes of first-language attrition that include loan translations (Ferguson 1997: 35, 47; Tóth 2007: 115-117). For instance, Pennsylvania German speakers in the US use the phrase Das hat sich besser ausgedreht, following AmE it turned out better, corresponding to standard German Das ist besser geworden/das hat sich besser entwickelt. Also, speakers of Latin American brands of Spanish may use the calqued construction aplicar para un trabajo < to apply for a job instead of the standard Spanish phrase solicitar/echar la instancia para un trabajo. As Lipski (2008: 226-229) shows, calques, as an indicator of relexification, are a partly stigmatized, but also frequent shibboleth among bilingual Spaniards in the US. Witness, e.g. verb 
constructions involving the preposition para atrás (usually pronounced patrás) such as llamar patrás 'to call back' and venir patrás 'to come back', or numerals as part of street names as en la 42 calle 'on 42nd Street", the exception being the Calle Ocho in Miami, a name 'correctly' coined by the first wave of Cuban immigrants. Worth noting are also free translations made by non-English speakers in bilingual cities like Miami such as the humorous phrase el pollo del viejito, lit. 'the chicken of the little old man'< KFC 'Kentucky Fried Chicken' (Sánchez 2016: 107). In Cuban Spanish, there are also slang expressions that are structurally and pragmatically mapped on English models such as patear la lata 'to pass away', lit. 'to kick the can'< to kick the bucket, arriba de la bola 'to be in an alert manner'< on the ball (adv.), novela jabonera, lit. 'soap novel', patterned after soap opera (Sánchez 2017).

Having discussed the impact of extralinguistic motives and conditioning factors, let us now direct our attention, again from a comparative perspective, to the linguistic factors that may be decisive in processes of calquing.

\subsection{Linguistic factors}

\subsubsection{Semantic transparency}

For speakers of a Romance language like Spanish, which relies more heavily on inflection in its verbal morphology and for the purpose of designating gender, it may be hard to memorize morphologically complex anglicisms. Thus, such English expressions may be replaced through calques. This reduces the cognitive load as calques usually, though by no means always, converge with the morphosyntactic norms of the native language. Provided that the equivalent is semantically transparent and supported by a sociolinguistic setting generally in favour of calques, the chances for the replacive form gaining a foothold increase. Interestingly, calques may be directly coined even without there being any significant evidence of previous uses of the respective anglicism serving as a model. Good examples of this are the Spanish compounds libre comercio<free trade, sexo en grupo<group sex, sexo seguro <safe sex, microondas<microwave. All items in the list spring from a word-by-word translation, which is even simpler in German because of its close relation to English. Thus, we have Ge. Freihandel, Gruppensex, and Mikrowelle (the nominal anglicism Safe Sex is usually retained in German). The method of finding a word-by-word translation is straightforward, and it does not require much effort since the structure of the English models is readily analysable. 
The readiness for calquing is further increased if the English term is built on Latin/Greek elements which are internationalisms, i.e. exist in a similar form and meaning in other languages. For the sake of illustration, let us briefly consider here the noun-noun compound data bank 'a store or source of data'. The two building blocks this compound consists of have close cognates of similar form in most European languages. Therefore, it seems natural to use the corresponding native forms of these words to produce lexical surrogates. As indicated in the following extract from $D E A$, it is only the Dutch and Norwegian nouns that entirely match the English form and thus are no calques: Ge. Datenbank, Dut. databank, Nor. databank, Ice. gagnabanki, Fr. banque de données, Sp. banco de datos, It. banca dati, Ro. bancă de date, Pol. bank danych, Hun. data-bank, and Gr. trápeza dedómenon.

English noun-noun compounds with their typical 'regressive' order (modifier + head) are sometimes translated with the much more frequent 'progressive, 12 pattern of the Romance languages where the head is preposed to the modifier. Such is the case of skyscraper, rendered with the formula ' $V+$ direct object', which give rise to exocentric compounds where the head is elided: e.g. Fr. gratte-ciel, It. grattacielo, Sp. rascacielos, Por. arranha-céu, Ro. zgârie-nori (lit. 'scrapes-clouds'). In English this constructional pattern is not so common; it is only used sparingly in pejorative words such as cutthroat, pick-pocket, killjoy, and turncoat.

The situation is a little different with the compound space shuttle since the calques contain constructions replacing the nominal determiner found in English. In fact, the Spanish calques are aeronave/nave espacial, similar to Fr. navette spatiale while German has no need for such a transformation due to the preference of noun-noun compounds: the established calque thus is Raumschiff. By contrast, World Cup has been partly translated into Spanish (cf. Sp. copa del mundo) as well as into other languages: Ge. Weltcup, Dut. wereldcup, Fr. coupe du monde, It. coppa del mondo, Ro. cupa mondială, Rus. kubok mira. Not surprisingly, the DEA entry shows that German and Norwegian preserve the English form with considerable frequency, but also use native terms, i.e. Weltcup and verdenscup respectively.

If we stay within the same lexical field, but look at an expression used in soccer terminology, namely Champions League, we can see that there are also exceptions in the Romance family. Although the calque Liga de Campeones is sometimes used in Spanish, too, the anglicism persists as it does in German. Especially in speech, an elliptical pseudo-English form - Champions - is well

12 The terms 'progressive order' and 'regressive order' are used by Picone (1996: 18) and Rodríguez González (1988: 68). 
documented. Several reasons may account for this: first, the availability of a cognate noun (here: liga); second, the stronger recognition value of the internationally accepted term, which is a proper name, and third, the fact that the lexical import is not as semantically ambiguous as the direct translation, which might, in principle, refer to any league of champion players.

With regard to the criterion of semantic transparency at least one tendency can be found valid across language boundaries, namely that blends are rarely calqued because of their condensed structure. Thus, forms like sexting (blend of sex and texting) and smirting (blend of smoking and flirting) do not readily get calqued. It is not by chance that blends and other ludic forms, e.g. words containing rhymes like shareware and pet-set (an analogous formation inspired by jet-set; referring to special facilities for pets, usually serving a wealthier clientele such as pet hotels, providing day care for domestic animals) are generally hard to translate (for a study on the translation of blends see Cacchiani 2016). There are some exceptions, such as the atmospheric term smog, which is also rendered as niebla tóxica, niebla contaminante, or bruma industrial in Spanish and as Dunstglocke, Dunstschicht, Dunstschleier, or Schmauch in German.

\subsubsection{Influence of register and frequency}

While anglicisms often find a niche particularly in specialized language, calques rather relate to the needs of the everyday language user and may help to popularize certain technical concepts (cf. Gómez Capuz 2005: 39). For instance, German postal terminology was largely dominated by French in the nineteenth century before it became the target of Germanization attempts which chime in with the decreasing prestige of French and the growing relevance of mail services in everyday life. Even today, calques that are well embedded in everyday language use frequently serve as labels for popular or life-determining things, activities, etc. Note the translation of terms such as airline (Sp. aerolínea, línea aérea; by contrast, Ge. Fluggesellschaft is slightly more formal), airmail (Sp. correo aéreo, Ge. Luftpost), and brainwashing (Sp. lavado de cerebro, Ge. Gehirnwäsche). The translation of these lexemes has been facilitated by the fact that both head and modifier are basic vocabulary items and form a semantically transparent compound.

There are circumstances which, linked to the meaning of the respective anglicism, may impede the coinage of calques even if the latter meet the previously described conditions. One option is that a direct (literal) translation of at least one of the elements of a compound loanword would provoke a 
“polysemic clash". Consider, for example, the expression taxi-girl which refers to a dancer in a cabaret or a woman paid for dancing with customers. It is not only documented in Spanish, but also inventoried in TNDP (2006: 1936), where the synonym taxi dancer is listed. Although taxi girl has dropped out of Spanish contemporary usage, it is obvious how misleading any calque, especially a literal translation like Sp. ${ }^{\star}$ chica de taxi, would have been. The signification of this expression comes quite close to the metaphoric meaning underlying the aforementioned equivalent taxi dancer, described in more neutral (i.e. nonsexist) terms by the $C O D$ as a 'dancing partner available for hire'. The two structures are therefore similar if we take into account that in the Spanish word a qualifying element has been elided since the anglicism could be conceptualized as "a taxi(-dancing) girl". The meaning of taxi in this endocentric compound contrasts with that of the compound taxi man 'taxi driver'. In parallel fashion, playboy and playgirl are not calqued in Spanish because their meaning cannot be completely inferred from a literal analysis of the two elements of the term ('a boy/girl who plays'). Although the juxtaposed elements show a semantic relation that describes the adventurous outlook on life, in this instance the term boy usually connotes 'a (wealthy) womanizing man' (not a literal boy), and by the same token, the appearance of girl in the parallel construction usually connotes 'a sexually liberated (but typically young) woman'. So neither boy nor girl can be taken at face value. In German, there are the (now obsolete) compounds Lebemann lit. 'man enjoying his life' and Salonlöwe, lit. 'salon lion', but their meaning is slightly different and somewhat derogatory.

Similar to what is at stake with the lexical pair taxi man and taxigirl, the different semantics of the terms barman and barkeeper reflects a case of linguistic sexism. In contrast with En. barkeeper (sometimes barkeep) and bartender as well as the borrowed Italian term barista, current in Spanish and now also in English, all of which are gender-neutral descriptives (this despite the - $a$ ending on barista), standing for a 'person who serves drinks at a bar' (or, more often in the case of barkeeper, 'a bar owner or operator'), barman strongly connotes a male occupation. This word has developed a second technical meaning 'a man specialized in concocting cocktails', recently substituted in the specialized jargon by mixólogo, calqued from English mixologist (cf. GDA). By contrast, the term bargirl, differently connoted, refers to a girl whose main activity is just to encourage the clientele to spend more money on drinks. For euphemistic reasons, this anglicism was later on substituted by the calque chica de barra or chica de barra americana in Spanish, barra americana being a synonym for 'nightclub'. The alternative loan translations whiskera and güisquera have a more slangy tinge, but also a more general meaning which alludes to roughly the same concept: a place where customers 
can have whiskey cocktails and, at times, also sex. Both terms have become obsolete (cf. Rodríguez González 2011).

Almost the same remark could be made about call girl 'prostitute', as there is also a euphemistic intention, which has paled in the case of the loans playboy and playgirl. ${ }^{13}$ A closer look at the usage of call girl shows that the loanword dominates in most European languages, either keeping its English form (cf., for instance, German, Norwegian, Romanian, Hungarian, and Spanish) or showing some orthographic or morphological adaptation (cf. Cr. kolgerl, Bul. kolgŭrla, Gr. kol gerl). The only exceptions are It. ragazza squillo (lit. 'ring girl') and Rus. devushka po vyzovu (lit. 'girl (available) on call') - two elements that co-occur along with the anglicism. By analogy, call boy in its meaning 'male prostitute' has not been translated (cf. GDA), probably because of the social taboo associated with the idea of men earning their living this way. In fact, related slang terms such as Sp. chapero or Ge. Stricher are semantically less specific and more pejorative than the anglicism. ${ }^{14}$

Another illustrative example is dark room 'a darkened room where people meet for anonymous sex', especially in homosexual subculture. The expression is descriptive, and in its specialized meaning it is restricted in usage and rarely found in writing, being usually translated as cuarto oscuro in Spanish. This is revealing as the term forms part of sexual terminology, a domain where anglicisms flourish because of their euphemistic function so that it is not at all astonishing that German does not habitually use a calque here (cf. Rodríguez González 2008: 257). Occasionally, the pseudo-borrowing black room is used as a synonym in Spanish.

A further expression worth noting is cabezas rapadas 'skinheads'. Even though the compound is exocentric (the complete form would be un [hombre con la] cabeza rapada 'a man with a bald head'), the prototypical idea of what makes a skinhead is well-known. This factor may have facilitated the formation of calques - at least in Spanish. German, however, prefers the anglicism, which may be abbreviated to Skin (a likely direct borrowing, since skin is quite current in English as well). The same abbreviation is used in Spanish.

13 There is of course a sexist double standard at work, based on traditional social norms, such that the male form playboy can often carry somewhat 'positive' connotations, referring to a Don Juan, whereas the parallel female forms playgirl, bargirl and call girl, when it comes to sexual innuendo, can carry 'negative' connotations, referring to women of 'low morals', as traditionally viewed.

14 By contrast, the use callboy as a designation for a man in a theatre who summons the actors needed on stage matches the Spanish terms avisador and traspunte which do not seem to go back to English influence. 
On the whole, there do not seem to be as many calques in the area of slang, although the fact that they are linked to the use of native terminology in the recipient language may make researchers only discover the most salient examples. Still, the expressiveness of some metaphorical slang sayings, constructions, words may also be adequately conveyed by native equivalents. Thus, highbrow and egghead are used in Spanish, although infrequently, with their meaning of 'intellectual', in stylistically marked contexts to refer disparagingly or facetiously to a pretentiously cultivated type. But the connotation is conveyed in a more straightforward manner by the calques (gente de) ceja alta and cabeza de huevo respectively. According to DEA, egghead, also meaning 'expert', has been translated as well into Fr. tête d'œuf, It. testa d'uovo, and Hun. tojásfejü. The anglicism itself is attested with low frequency in colloquial German (although there is also the form Eierkopf), Dutch, and Norwegian.

\subsubsection{Length}

Examples like high fidelity and high technology also reveal that the length of an anglicism can be a determining criterion. Such longer descriptive compounds more easily lend themselves to translation in a resultant calque (e.g. Sp. alta fidelidad, alta tecnología; German only has a calque for the second term, namely Hochtechnologie or Spitzentechnologie). However, if longer English compounds are shortened and turn into buzzwords, they are more apt to be borrowed ( $h i-f$, high-tech). Accordingly, if the translation of a short borrowing results in a longer expression, the calque is likely to fail. For instance, the two-syllable unit password was originally translated as palabra de paso in Spanish computer jargon, but due to its complex structure (3 words, 6 syllables) the loan creation contraseña (1 word, 4 syllables) has prevailed over código (de seguridad) and the rarely used alternatives clave de acceso and clave personal. In French, however, the three-syllable translation mot de passe is common and, at the oral level, it is typically reduced to a two-syllable expression; hence [modəpas] $>$ [modpas]. Ge. Passwort, in turn, is close to the English model.

At times, two powerful motives such as brevity and semantic transparency might compete and therefore trigger variations. For instance, in Spanish the loanword e-mail, a clipping of electronic mail, and the calque correo electrónico co-exist. Although the recency of this loan does not permit any safe conclusions about possible future developments, we find different distributions across different receiving languages. According to $D E A$, the Germanic languages, i.e. German, Dutch, Norwegian and Icelandic, have adopted the loanword more readily whereas other European languages prefer the calque. But even in the 
latter case usage often varies. Thus, both the loanword and the calqued forms (Fr. courrier électronique, It. posta elettronica, Cr. elektronska pošta, Bul. elektronna poshta, Rus. élektronnaja pochta, and Pol. poczta elektroniczna) are used, although the calques are considered slightly more formal. ${ }^{15}$ In Spanish, the use of e-mail and, still shorter, mail (also used in, e.g. German and French), is gaining ground in speech to an extent that sometimes one finds the humorously derived verb e-mailear as well as the slang form emilio (by analogy with the homonymous proper noun Emilio). In France, mail (sometimes mél, e-mail, email) now far surpasses courrier électronique (as well as courriel, imported from Québec) in common usage, both written and oral.

As to the supralexical level, there are fewer examples of borrowings like the catch phrases business is business and to be or not to be, which are attested in Spanish and German. However, in general, fixed expressions are more prone to calquing despite growing trends of anglicization, as they usually entail a higher cognitive load because they contain sequences of nouns, verbs, and possibly also adjectives, adverbs, and function words. For instance, Spanish politicians and journalists may be found using the formula mantener un perfil bajo < to keep a low profile (originally an American military expression; it is also current in French as adopter un profil bas, Picone 1996: 101). In general language use, we also come across expressions like Sp. llorar sobre leche derramada/Ge. über verschüttete Milch weinen < to cry over spilt milk, Sp. estar en el mismo barco/ Ge. im gleichen/selben Boot sitzen<to be in the same boat. In German, expressions such as am Ende des Tages < at the end of the day and Zeit ist Geld<time is money are employed. Sometimes, semi-calques like in der Pipeline sein < to be in the pipeline are found, too (Fiedler 2014; Nefedova and Polyakov 2014: 148-149).

\subsubsection{Medium of communication: spoken and written language}

Anglicisms may come up both in spoken and written language. This also goes for calques, although the distribution according to the medium of use is not clear. Hence, it will need to be researched for individual languages whether the spoken or the written channel served or serves as the major entry gate, acknowledging that the boundaries between the two have become fluid through modern media and trends of informalization in written use.

15 In German, the forms elektronische Nachricht or elektronische Post are not widespread. Moreover, the term E-Brief 'e-letter', which the second author of this article spotted in an answer letter of a member of the German Parliament (personal communication, 2001), has meanwhile become a brand name. 
German equivalents which were devised for foreign labels for inventions made in the field of telecommunication technology in the twentieth century were often formal and dominated by the norms of the written code. This can be illustrated by the official term Fernsprecher (lit. 'remote speaker') for Telephon/ Telefon 'telephone', which has meanwhile become anachronistic. However, calques may also be coined in spoken use and then enter the written language. A modern Spanish example is the popular pago por vision which followed the loan pay per view, which dominated the TV section of newspapers for a time. Other examples include Sp. agujero negro/Ge. schwarzes Loch<black hole, Sp. centro de jardinería/Ge. Gartencenter < garden centre.

A recent example, undoubtedly originating in the written language, is Sp. pato cojo/Ge. lahme Ente<lame duck, as used in political jargon. In Spanish political reports pato cojo was used in brackets following the anglicism, but nowadays the calque has become established.

Conversely, a popular expression has its source in oral language, as it is illustrated by Fr. marché aux puces, from which En. flea market and Ge. Flohmarkt ultimately derive. Although the concept of a market selling second-hand goods and various products and services in the open air has an ancient origin difficult to trace, the Paris Marché aux Puces, better known as Les Puces, became well-known in the nineteenth century and had imitators all over the world. The OED lists evidence of the use of flea market since 1922. As for Spanish, the loan translation mercado de las pulgas was recorded in 1927 by the Guatemalan journalist Miguel Ángel Asturias (cf. CORDE), and in Spain by Baroja in 1941 (cf. Del Hoyo 2012). However, this calque is infrequent today and in its place many other native alternatives are used, such as the old colloquialisms mercadillo and rastro (after the famous 'Rastro' held on Sundays in Madrid), which are deprived of negative connotations.

\subsubsection{Elapsed time}

In the course of time, under conditions favouring tendencies of nativization, borrowings may yield to calques, as the aforementioned example pago por visión < pay per view shows. For this process, football terminology provides significant evidence. In the early stages of the sport in Europe, there was an obvious need to borrow the English terminology, just as today English dominates the jargon of windsurf and golf. Later on, however, the foreign items were replaced in Spanish, German, and other languages, as the following DEA entries show: Sp. delantero centro/Ge. Mittelstürmer<center-forward; Sp. defensa central/Ge. Läufer<half back; Sp. saque de esquina/Ge. Eckstoß, Eckball<corner kick; Sp. área de castigo/Ge. Strafraum<penalty area. 
The time factor may also account for the diverging behaviour in different languages regarding some borrowings, such as forehand in tennis terminology. Some languages have replaced the late nineteenth century loan by a calque (e.g. Ge. Vorhand, Ice. forhönd) and others by a loan creation (e.g. Fr. coup droit) and semantic innovations (e.g. Sp. derecha, and It. diritto). In contrast, the recent popularity of tennis appears to have prompted the use of the loanword in other languages: Ro. forhend, Rus. forkhénd, Pol. forhend/forhand, Cr. forhend, Bul. fokhend, Hun. forhand, and Gr. forkhad.

As to the Germanic languages, most notably German and Icelandic, the process of translation in the case of the term forehand was probably facilitated by the existence of native equivalents which are cognate with the source items. The fate of another English tennis term, deuce, was different in Spanish. Going back to Old Fr. deus (from Latin duos) 'two', the term is used when the match opponents are tied at 40-40 and one or the other needs to win two consecutive points in order to prevail in the game. As this monomorphemic unit is not further analysable in Spanish, Spanish speakers have coined a more descriptive term, namely the loan creation iguales, which focuses on the fact that the players are tied in the set at 40 apiece. Nowadays, this promotes considerable variation between the borrowing and calqued form. This is comparable to German where native Einstand and the anglicism Deuce co-exist; their use by umpires may depend on the size of a tournament while tennis fans and players may have individual preferences.

Finally, the form anti-aging was formerly translated into Sp. antienvejecimiento, but for euphemistic and marketing reasons the calque anti-edad is preferred today since the prestige of English is generally high in this domain (cf. Koll-Stobbe 2005 for German; Balteiro and Campos 2012 on the use of pseudo-anglicisms in Spanish beauty and fashion).

To check whether similar patterns are found in other parts of the vocabulary, too, the disposition of different languages for calquing depending on the age of the loan will have to be investigated across various lexical fields.

\subsubsection{Variation between borrowings and calques}

Reflection on the reasons for the variation between the anglicism deuce and replacive forms like Ge. Einstand or between lobby and the expression grupo de presión < En. pressure group leads to another question. When faced with the option of either borrowing or arriving at a calque, which factors are decisive in determining the outcome? Are they sociolinguistic (i.e. dependent on age and education or register; for example, the particular preference of journalese for 
anglicisms), are they stylistic (e.g. to avoid repetition) or do they help to differentiate meaning? Moreover, do they (also) depend on linguistic factors such as word class? That the latter option may also play a role becomes particularly evident when studying sets of words in the same language that are morphologically built on a loanword in some cases and on the respective calque in other instances. This is the case with waterpolo, for example. Designating a game played by swimmers with a ball similar to a volleyball, it co-occurs in Spanish with the less used term polo acuático whereas Italian has coined the more frequent native term pallanuoto. In deviation from this form, the derivative waterpolista is built on the borrowed unit. Similarly, Bulgarian vaterpolo co-occurs with the native creation vodna topka, which DEA marks as more frequent, but the derivative is polist (also cf. the forms vaterpolo/vodnoje polo and vaterpolis in Russian). An interesting alternation is illustrated by another example. In general, French prefers the acronym OVNI (short for 'objet volant non identifié') over the anglicism Ufo, but the latter is more felicitous at the phonological level when it comes to blending with the -ologie and -ologist thematic suffixes (ufologie, ufologiste), used in scientific contexts. Spanish and Italian follow the same line (see Sp. OVNI=Objeto Volador No Identificado vs. ufólogo/ufología; It. oggeto volante non identificato, disco volante vs. ufologia and ufologo). Sometimes even two derivatives exist, as with Sp. futbolista or, more rarely, futbolístico and balompédico. Additionally, the literary form balompedista may be used as an adjective or a noun. This is different in German which is consistent across different parts of speech, using Wasserball 'waterpolo' and Wasserballspieler 'waterpolo player' or Wasserballer, similar to Fußballer 'footballer' and $U f{ }^{16}$ plus Ufologie.

A loanword and the calque that was coined to replace it may differ in use and meaning and may end up occupying different (but typically related) semantic fields. Thus, as already mentioned, barman, GDA). currently used in most European languages with the meaning 'a man serving drinks behind the bar of a public establishment', co-exists in Spanish with camarero (de barra), but the borrowing also has adopted a specialized meaning: 'someone who concocts cocktails'. A similar semantic difference exists between facelift(ing) or the front-clipped variant lifting 'cosmetic surgery to remove wrinkles' and equivalents which have

16 The German Duden states that a Ufo is an "[...] unbekanntes und nicht identifiziertes Flugobjekt". A literal translation of the English full form unidentified flying object would be "nicht identifiziertes Flugobjekt". However, the adjective unbekannt is added to motivate the form in German. Here, the $u$ suggests the idea of something unknown instead of merely talking of an 'unidentified flying object'. We would like to offer our thanks and appreciation to one of the anonymous reviewers of an earlier version of this article who brought this to our attention. 
been formed in Spanish and German. Lifting is used when plastic surgery is the reference field. In German, this notion might also be conveyed by the longer technical compound Gesichtsstraffung or, the less specific, Hautstraffung. In Spanish, the anglicism co-occurs with the calques estiramiento, estiramiento de piel, estiramiento facial and ridectomía. While the loanword lift(ing) may also be employed metaphorically in both languages so as to refer to renovations or procedures for improving the appearance of something, this does not hold for the respective native surrogates. Moreover, when euphemistic intentions prevail, the anglicism is preferred because it has less negative associations. Alternatively, other expressions such as maquillaje or lavado (de imagen/de cara), puesta al dia, actualización, modernización or remodelación may be used in Spanish.

\subsubsection{Stylistic variation}

Even if the meaning of a calque and that of its English model term are very close to each other, synonymic variation may be a factor, for instance in press texts. A Spanish journalist, after using the anglicism sprinter several times, may wish to use a calque such as velocista to avoid cacophony. Examples of this kind can be found in many languages, e.g. the side-by-side use of Keeper and Torwart in German. These choices are by no means limited to technical language.

\section{Different forms of calquing}

As introduced in Section 2, calques occur in different guises. This section tries to elucidate when loan renderings instead of exact translations may emerge. A specific type of rendering comes into being when only one element of a compound is translated, a phenomenon also called 'semi-calque' or 'partial calque'. Sometimes syntactic or semantic factors are influential here.

\subsection{Constituent structure}

Compound anglicisms containing an adverb or particle are particularly prone to syntactic change. Consider, for example, the noun centre forward 'a middle player or position in a forward line'. This term was adopted due to the spread of football sports but has been replaced by calques in many European languages. In the English compound a substantivization has taken place allowing forward to convert to a noun by suppressing the head in expressions such as 
forward player. The head, which is now the noun forward, is modified by the adjectival use of centre. This is imitated by the corresponding equivalents found in French and Italian, viz. avant-centre and centravanti, which form exocentric compounds as in the English model. Other languages opt for a calque in terms of an endocentric compound by replacing the adverbial particle by a noun referring to a person, thus making the term more descriptive (cf. Ge. Mittelstürmer, Fin. keskushyökkääjä, lit. 'centre attacker', and Sp. delantero centro). Yet, these structural similarities do not erase slight semantic differences: while the Spanish term alludes to the position of playing ('located in the centre'), the German and Finnish ones refer to the role of the player ('attacker'), similar to the Italian equivalent, namely centrattacco, albeit with the difference that the noun attacco, lit. 'attack', has a non-personal reference. The following list captures the usage in other European languages as recorded in DEA: Nor. senterforward, apart from the loan translation senterløper, Ice. - < loan rendering framherji, Ro. - < loan rendering centru înaintaş, Rus. tsentrforvard $<$ loan translation tsentral'ny̌̌ napadayushchǐ̌, Pol. - < loan creation napastnik środkowy, Bul.-<loan translation tsentǔr napadatel, and Alb. - <qëndër sulmues.

From the perspective of constituent structure, we may also comment further on an example already discussed above, forehand, which, like centre forward, combines a preposed modifier (fore- in the former case, and adjectival centre in the latter) and a noun (hand and substantivized forward). While French has developed a loan translation, coup droit, Spanish and Italian have coined loan renderings, i.e. Sp. derecha and It. diritto, where one element has been elided. Still, the prestige of English has led to the importation of the anglicism in other European languages, at least in technical use: Ge. Vorhand, Dut. voorhand, Nor. forhand, Ice. forhönd, Ro. forhend, Rus. forkhénd, Pol. forhend/forhand, Cr. forhend, Bul. forkhend, Hun. forhand, Gr. forkhad.

Some English compound expressions, especially those where the second element is a gerund, translate into an adjectival participle in Spanish. Examples of such syntactic recasting are tiempo compartido, lit. 'shared time' < time-sharing, and aire acondicionado, lit. 'conditioned air' < air-conditioning. Tiempo compartido is used in the field of computers, but it also refers to the sharing of a holiday home by several owners. In the latter case, the loan creation multipropiedad is used alternatively. A parallel phenomenon is noticed in French with temps partagé and multiproprieté. As for aire acondicionado, early on it was considered by Lorenzo (1996: 91) to be a calque from English, but that assertation is not tenable since the chronology of attestations shows that the mediation of French was decisive. The technology of air conditioning was invented at the beginning of the twentieth century by a North-American engineer, Willis Carrier, and became known in Europe after World War II. The term designated the 
system as well as the apparatus for regulating the temperature of a building, and was used primarily as a gerundive noun, but also adjectivally. In time, from the alternative adjectival expression, air-conditioned, French obtained the calque air conditionné, around 1950 (cf. TLF), which morphologically was the model for Sp. aire acondicionado (attested in 1958, cf. CORDE), It. aria condizionata and Ro. aer conditionat. Sp. aire acondicionado was used for a time in adjectival expressions (e.g. equipo/sistema de ... aire acondicionado), or as a noun to refer to the system as a whole, but later also, by extension, to the apparatus itself.

Following the norms of the receiving language, loan renderings sometimes also go hand in hand with a shift in the grammatical category of number. This can be readily illustrated in the case of the replacive forms triggered by the anglicism intensive care in French (soins intensifs) and Spanish (cuidados intensivos), where the two constituents are pluralized. Due to grammatical congruency with English, comparable pluralizations are not found in the Germanic languages (see Ge. Intensivpflege, Ice. gjörgæsla).

\subsection{Semantic factors}

As relevant as these structural aspects may be, semantic factors are both more far-reaching and more subtle. Contrasting the semantic properties of the components of a compound anglicism and a calque, one may at times spot some differences regarding the semantics of the base element of the replacive forms. One of the reasons for this is that the receiving language creates new contexts of use, which may bring about a reinterpretation diverging from the original English concept, which then becomes associated with the calque. As exemplified below, this may be a conscious act and may have to do with the attempt to avoid semantic evocations deemed negative and therefore unwelcome. As such, techniques of semantic upgrading can be employed through calquing, exploiting metonymic relations or substituting one element by a more positive term.

\subsubsection{Avoiding cultural associations}

Occasionally, a literal translation of one element of a compound anglicism tends to be avoided because of problematic cultural associations in the receiving language. Speakers do not take offence at a literal translation of the lexical morpheme sky in skyscraper in Spanish, French, Catalan, Italian, and Portuguese where the forms rascacielos, gratte-ciel, gratacels, grattacielo, and arranha-céu have become institutionalized even though the term cielo/ciel/cel/céu in the Romance languages refers 
to both 'heaven(s)' and 'sky' ('the high altitude region of the clouds'), where 'heaven' can have a potential religious association. By way of contrast, in languages such as Arabic rendering sky as 'clouds' avoids unfavourable religious associations, hence the calque nạtihatu s-ihāab substitutes 'as-sihāa 'cloud' for 'as-samā 'sky', as the lexeme 'as-samā has, as one of its main senses, the religious notion of 'heaven' (cf. Ali 2005). Though not necessarily for religious reasons, German uses a similar loan rendering Wolkenkratzer (lit. 'cloud-scraper') and not the literal translation ${ }^{\star}$ Himmelskratzer. Probably, this is due to the polysemy of Ge. Himmel, which may refer to the sky 'the air above' but also means 'heaven'. This substitution of sky by cloud takes place in many other languages as well, e.g. Dut. wolkenkrabber 'cloud scratcher', Fin. pilvenpïrtäjä 'cloud sketcher', Est. pilvelõhkuja 'cloud-breaker', Pol. drapacz chmur, 'cloud-scraper', Ro. zgârie-nori 'scrapes-clouds', Sr. oblakoder 'cloud-ripper', Ukr. hmaročos), 'cloud-scratcher', Wel. cwmwlgrafwr 'cloud scraper'.

\subsubsection{Semantic upgrading via metonymic twists}

Apart from generating a more neutral replacive term, speakers, when forming a calque, may opt for a strategy of upgrading, through which the referent in question appears in a more positive light. For example, an analysis of the calques for bodyguard in different European languages shows that some of them translate both elements literally. This example is discussed here although it is likely that the English bodyguard (attested since the early eighteenth century) derived from Fr. garde du corps, which has existed since the end of the seventeenth century, ${ }^{17}$ a structure replicated in Dut. lijfwacht, Ge. Leibwächter (formerly used for the guards of kings), It. guardia del corpo and Ro. gardă de corp. In contrast to these languages, Spanish, Portuguese and Catalan render body or corps as 'back', resulting in Sp. guardaespaldas, Pg. guarda-costas, and Cat. guardaespatlles. This synecdochic use of the term (where the part 'back' stands for the whole) is likely to have been reinforced by cognitive networks. This is due to idiomatic expressions such as Sp. cubrir las espaldas 'to cover one's back' or tener cubiertas las espaldas ('to have one's back covered') as well as Pg. guardar as costas. The fact that unfair attacks come from behind and aim for the unprotected back may play a role as well. The Portuguese calque, lit. 'guard the back', is also remarkable insofar as it resorts to an already existing idiom, which creates a certain proximity to the category of semantic loans. Even more euphemistic is the reference in other languages such

17 Recorded in 1680, according to Rey (2005: 1271), whereas the first reference of bodyguard in the $O E D$ is from 1701. 
as in Fin. henkivartija which uses another synecdochic twist by substituting 'life' for 'spirit'.

Additionally, the calques replacing the anglicism headhunter illustrate the conditions under which loan renderings may be preferred. Whenever European languages do not use the anglicism, they translate headhunter literally; thus, we have Ge. Kopfjäger, Nor. hodejeger, Fr. chasseur de têtes, It. cacciatore di teste, and Hun. fejvadász. However, cazador de cabezas might sound a little crude to Spanish ears, leading to the metonymic recruitment of talento 'talent', a word devoid of any physical imagery or association to animals. It is true that Spanish sometimes makes use of the phrase tiene mucha cabeza, too, but its synonym tiene mucho talento is more formal and frequent.

The same holds for brainstorming. This compound noun appears to have been popularized in advertising circles. It is divided between 'colloquial' and 'technical' uses, with only a few calques available, e.g. Fr. remue-méninges, Sp. tormenta de ideas or lluvia de ideas, Bul. mozǔchen shturm, and Hun. ötletgyártás.

\subsubsection{Synonymic variation}

For the English expression flying saucer 'an unidentified flying object', virtually all European languages prefer calques, but they vary in the translation of the base of the compound, which is rendered either as 'saucer', 'disk' or 'plate', quasi-synonyms describing the shape of the object. The more literal first option, 'saucer', is followed by Ge. fliegende Untertasse, Fr. soucoupe volante, Sp. platillo volante, Dut. vliegende schotel, and Fi. lentävä lautanen. 'Disk', is found in Alb. disk fluturues, It. disco volante, Gr. iptámenos diskos, Nor. flygende tallerken, and Ice. fljúgandi diskur. Finally, Rus. letajushchaja tarelka and Pol. latajacy talerz literally translate as 'flying plate'.

An example of variation involving synonymy is also found in the translation of En. tax as part of the abbreviation VAT (Value Added Tax). Initials may be retained, especially in the case of names of institutions, whereas everyday language abbreviations are more readily adapted and calqued in individual languages. Thus, Spanish renders the base of the unit VAT as impuesto and uses the form IVA. The same pattern is followed by It. IVA (imposta sul valore aggiunto), but other languages use the form derived from Latin taxare (see Fr. TVA=taxe sur la valeur ajoutée; Ro. TVA=taxă pe valoarea adăugată). Taxe and taxă are, in a way, euphemistic, in the sense that they connote the regulation of a value; contrariwise, impuesto suggests an imposition. However, other factors like sonority are probably more relevant here. In fact, Spanish started to use TVA before this tax was introduced, following the French model, but later it changed to the 
nativized version IVA (see Rodríguez González 1991: 162-166 and 1993 for other examples of Spanish calques modelled on English acronyms and abbreviations).

Another case in point is the concept of visiting professor, which can be rendered in two different ways - either by using a qualifying native adjective equivalent to En. visitor, or by subtly modulating the agency and opting for the native equivalent of 'guest' or 'invited' in the modifier position. Among the European languages, Spanish, Greek, and Hungarian use a loan translation: Sp. profesor visitante; Gr. episképtis kathighiis, Hun. vendégprofesszor. Most other languages, including the Germanic ones and other culturally similar societies, use the loan rendering pattern: Ge. Gastprofessor, Dut. gasthoogleraar, Nor. gjesteprofessor, Ice. gistikennari, gestaprófessor, Cr. gost profesor, Bul. gost-profesor, Pol. profesor wizytujcy, and Alb. profesor i ftuar. Semantically, the loan rendering is somewhat more welcoming in tone, inasmuch as it foregrounds the agency of the receiving institution, whereas visiting implies the agency of the professor.

Another source of variation in calques is found in association with the concept of youth hostel. There are languages that resort to a loan creation such as Ice. farfuglaheimili, from farfugl 'traveller, itinerant' and heimili ('home'), or to various loan translations and loan renderings. One should remember that youth hostelling was first introduced in Germany in the early twentieth century and then spread elsewhere. The world's first Jugendherberge opened in 1912. Some scholars misidentified the original German expression as a loan translation from English. In 1932 the International Youth Hostel Federation (IYHF) was founded in Amsterdam, and from then onwards these initials became well-known. Given its origin, one can understand why most languages follow the translation pattern of Ge. Jugendherberge, as attested e.g. in Nor. ungdomsherberge and Fr. auberge de jeunesse. In Italian, albergo della gioventù occurs as well, but the most frequent term (and in fact the only one recorded in DEA) is ostello della gioventù. In Spanish, likewise, albergue juvenil and albergue para jóvenes co-exist with hostal juvenil as well as the anglicism youth hostel. The paronym hostal has not taken hold since it refers to a cheap hotel and would thus be more generic.

The expression duty-free shop is an obvious consequence of international air travel. The element shop is frequently omitted from the compound - apparently because it does not often appear on signs. This specialization probably makes the word different from native expressions/calques like Ge. zollfrei or Fr. hors taxe which may serve as epithets only.

Finally, let us comment on the equivalents found for the adverbial anglicism live, which also has currency and, because of its connection to the modern media and entertainment culture, largely prevails over potential loanshifts. If substitutes have been coined at all, they vary between expressions that use an equivalent to the English form, which evokes the idea of things in motion, and 
the form direct, which suggests that there is no time delay and/or filtering, but rather an immediate projection of what happens onto the television screen. Sometimes, alternating uses exist, e.g. Dut. levende and direkte, but also in Sp. en vivo and en directo and It. dal vivo and in diretta. Romanian and Albanian, by contrast, opt for the latter form.

Sections 3 and 4 have shown under what circumstances calques come into being and what engenders different forms of calquing, i.e. loan renderings instead of literal translations. The next section looks at variations in the use of calques within a given language as well as across different recipient languages.

\section{Variation in the use of calques}

\subsection{Diachronic variation of source terms}

A specific case of variation may arise when two calques created at different points of time compete in usage. For a very long time Spanish has used the term azafata (de vuelo) 'a stewardess in a passenger aircraft', which was coined after the model of En. stewardess and revived according to its old use as 'camarera de la reina' (a lady at the service of the royal household). Yet British English also used the form air hostess, which was calqued as aeromoza in South American Spanish and has a perfect reflex in Fr. hôtesse de l'air. Although azafata is well rooted in European Spanish, an even more literal calque, auxiliar de vuelo, which is similar to It. assistente di volo, has come into use in recent years, no doubt under the influence of Am. En. flight attendant and due to the search for more gender-neutral terminology. In fact, azafato, for the masculine, had a humorous tinge, ${ }^{18}$ which reminds one of the parallel with the shift from enfermera 'female nurse' to ayudante técnico sanitario, lit. 'sanitary technical assistant'. Undoubtedly, the American term has a more modern and technical connotation and a certain euphemistic touch, a feature characteristic of most changes in the names for professions today. Similarly, German, apart from the anglicism, also uses the term Flugbegleiter/in.

Another example illustrating diachronic changes in the use of calques pertaining to aircraft is the recent synonymic expression TCP (=técnico/tripulante de cabina de pasaje), sometimes jocularly reinterpreted by the workers themselves as técnico de carrito de papeo ('technician of the food trolley'). Today TCP

18 This is obvious for a Spanish speaker as azafato sounds awful because of the sound and the strange gender suffix. No male would apply himself such a label. 
is used in the jargon of flight personnel as well as in the publicity adressed to potential job applicants, leaving azafata for more general use. German prefers the more generic term Bordpersonal 'board personnel', while the expression Saftschubse 'trolley dolly', (lit. 'juice pusher', which also entered the Duden), has a clear negative connotation.

\subsection{Diatopic inter-intralinguistic variation of calques}

As already pointed out, calques may vary in different (regional) varieties of one language as well as between different languages. As to Spanish, it makes sense to compare the European and South American varieties, since they sometimes follow different models, orienting themselves more to either English or French, languages with which they have competed for a long time. For instance, European Spanish uses ordenador<ordinateur, horas punta<heures de pointe, and Asuntos Exteriores<Affaires étrangères, by analogy with the respective French expressions. In South American Spanish, which is more influenced by English, we find computadora<computer, horas pico<peak hours, and Relaciones Exteriores < Foreign Relations. Regarding German, football terminology varies: Austrian and Swiss German are more likely to use Goalkeeper, for instance, whereas German German habitually uses Torhüter/Torwart, although this term may vary with Goalkeeper or Goalie in journalistic use (see above).

\subsection{Multiple calques and translations}

As was shown above, different calques for one and the same anglicism may emerge. If different replacive forms exist in one language and these are quasisynonymous, the use may be regionally or stylistically determined. In other cases, other forces may be at work.

\subsubsection{Multiple meanings of a word}

To begin with, multiple calques may be formed according to the various meanings a borrowing has. Thus, hotline - a term from the technical and political register also occurs in translated form in many European languages. In Spanish, the translation is teléfono rojo in this sense, but the loanword also has a special meaning in sexual jargon, 'a telephone line for exchanging erotic messages' which is translated as linea caliente. Often, the calque is thus used for the 
'innocent' meaning, while the loanword has a sexual connotation as well. This also holds for German, which does not have several native equivalents for hotline, but only the loan translation heißer Draht, which is employed in a similar fashion as teléfono rojo.

\subsubsection{Figurative meaning vs. opacity of the borrowing}

When speakers, for whatever reason, avoid the continued use of a previously employed borrowing which initially accompanied the introduction of a new concept, lexical creativity is put to the test. An example of this is the case of think tank. The figurative use of the head, which may not be transparent to nonnative users, may explain the fact that there are numerous calques even in a single language like Spanish (e.g. grupo de cabezas pensantes, tanque de ideas, tanque de pensamiento, creadores de ideas, and laboratorio de ideas) next to freer translations that are listed in some dictionaries (gabinete de estrategia, comité asesor). German is similar although the native synonyms Denkfabrik and Ideenfabrik are most frequent.

As outlined in Section 2, the number of loan creations, in comparison to that of literal translations, tends to increase if the use of the latter leads to a polysemic clash and to negative or less beneficial connotations. This is well illustrated by the large number of designations for 'a tunnel-shaped airport walkway connected directly to the plane to facilitate the boarding and unboarding of passengers'. Among the most common terms used in English, the words airbridge, jetbridge, jetway, jetty, and gangway (borrowed from nautical usage) stand out in addition to the official industry name passenger boarding bridge (PBB). In Spanish there have been proposals of all types, ranging from the most technical ones to the purest slang, amongst them pasarela telescópica, dique, embarcadero del aire, túnel extensible, embarcadero, mangada, tubo telescópico, and gusano. Other suggestions include pasarela, fuelle, espigón, pasadizo, tubo, trompa, or even manga or manguera, as it was called until recently by the employees of Madrid Airport. Against all these terms finger stands out, which was considered an anglicism by Lorenzo (1996: 213) but has practically no currency in English. García de la Cuesta (2003) records it as a translation under the entry airbridge, but it is not lemmatized. The GDA has marked it as a pseudoanglicism, and a Spanish official institution known as Fundéu (Fundación del Español Urgente) criticizes the term on the ground that it does not exist in English and recommends pasarela instead. But in Spanish finger is growing in frequency and recorded as such by the most influential dictionaries of usage (Seco et al., Moliner, CLAVE, VOX). Using the international lingua franca of 
airline employees, the English term finger has been pressed into service by Spanish personnel as a succinct and convenient metaphor which, moreover is deprived of the derisive associations which the Spanish translation, dedo, would have given rise to. In English and the German word finger are cognates. Although Finger, as a semantic loan, can be found in specialized (informal) use in German, the formal terms Fluggastbrücke and Passagierbrücke<En. passenger boarding bridge and the loanword Gangway are more common in the German context.

The English adjective queer, the original primary meaning of which was 'weird, slightly odd', which later became a common pejorative term for 'homosexual, gay', is partially parallelled by marica 'fag', torcido 'twisted', and raro 'weird' in Spanish. Subsequently English queer was re-appropriated by the subculture itself and freed from its pejorative connotations. Accordingly, in Germany, the anglicism now dominates in cultivated discourse. Meanwhile the traditional Ge. adjective schwul has followed a similar trajectory inasmuch as it has been reappropriated by the gay pride movement.

Sometimes different calques stand for different conceptualizations. For instance, there are different replacive forms for En. Hangglider in German. It is often substituted by the exact translation Hängegleiter but there is also the rendering Drachengleiter. While the first form is more technical and stresses the quality of the gadget as "a suspension glider, controlled and stabilized by deliberate movements of the operator's body” (OED), Drachengleiter (lit. 'dragonglider') compares the mechanisms to the way dragons manage to fly, thus creating a metaphorical and mythological dimension, linked to the old dream of humans being able to fly despite their relatively heavy weight.

These observations underline the complexity of factors that play a role in the production of calques. A problem area not yet discussed in detail concerns challenges that may arise when it comes to the identification of calques. Again, language-specific as well as generally valid aspects need to be discussed. In this respect, we will have to return to some of the points already referred to above.

\section{Challenges concerning the identification of calques}

\subsection{Far and near etymology of the calques}

To begin with, it may be difficult to clearly trace the origin of some calques back to an English model, just as happens with some borrowings proper, given that processes of transfer may involve several mediating languages. In reviewing the 
literature on the subject one can find, in effect, a number of examples that have traditionally been explained as direct calques of English expressions when in fact they are probably assimilations from some neighbouring European language. For instance, En. Value Added Tax (VAT) is historically calqued on Ge. Mehrwertsteuer, but English helped to pass on the term to other languages. Similarly, superman $<$ Ge. Übermensch and handball are of German origin. By contrast, brainwashing, having world-wide currency to designate a form of treatment of political prisoners, is said to be a calque on a Chinese expression of the 1950s (Görlach 2002: 35, 340) - just like the proverb chasing the dragon. In Spain, Emilio Lorenzo (1996: 500) called attention to the ease with which some forms were questionably attributed to English. As examples he cites: Sp. hombre de letras, derived from Fr. homme de lettres, but comparable to the English cognate man of letters; Sp. la misma cosa calqued from Fr. la même chose and not from En. the same thing; and neologisms such as Sp. centro comercial, translated from Fr. centre commercial, in its turn adapted from En. shopping centre. (Lorenzo 1996: 571); Sp. ciencia ficción, from Fr. science-fiction (the latter being a prior integral borrowing from English), admitted by the Spanish Academy in 1984, which competed with the proposed alternative ficcion científica (Lorenzo 1996: 571-572). He also examined the origin of Sp. caballo de vapor, from Fr. cheval-vapeur, itself freely calqued from En. horsepower (forged during the Industrial Revolution for calculating the energy of a motor vehicle in comparison with the force of a horse but replacing the second element with vapeur in an analogy to steam-driven machinery. This usage, often known today simply by the initials H.P. or C.V., has left its imprint on colloquial language, but the ellipsis of vapeur/vapor is typical. A well-known commercial name of a French automobile was the Citroën $2 \mathrm{CV}$, popularly referred to as the deux-chevaux (or Deuche) in France and as Dos caballos 'two horses' in Spain, where it was also manufactured (Lorenzo 1996: 567-568).

The issue discussed in the preceding paragraph leads us directly to the inescapable problem of chronology, i.e. the task of establishing a reliable method for finding out in which language a term occurred first. A point worth noting is that many borrowings may be of English origin but have been previously mediated via French, which produced calques that were a model for other (Romance) languages, as Santoyo (1988: 94-96) illustrates with a long list of examples. There are also cases like Sp. librepensador which is usually attributed to En. free thinker (cf. Lorenzo 1996: 484) but whose close etymon seems to have been Fr. libre penseur. Coined in 1659 (cf. Rey 2005), it entered general use in the first half of the eighteenth century and spread all over Europe and the US in the second half, during the Enlightenment, thanks especially to the writings of the philosophers Voltaire and Diderot. 
Especially in connection with more common or everyday concepts, the problem of chronology is sometimes even more acute and therefore, in principle, unsolvable. In some cases, one could also envision a 'polygenesis', i.e. the possibility that the same patterns may have emerged in two or more languages independently from one another with a barely noticeable difference in form and meaning, as with 'global metaphors'. For instance, how can we know whether foothill appeared before the Sp. estribaciones? The same holds for metonymic uses. Here, we might give the example of Sp. chupar and En. suck in the field of eroticism or Sp. ocuparse and English occupy 'perform sexual intercourse with a client (in prostitution)' (cf. Rodríguez González 2002b: 163).

Looking at more technical registers, where most calques emerge, the problem is less pronounced, especially when it comes to inventions of new concepts, at least if there is enough extralinguistic knowledge at our disposal. Even then, however, certain lexemes may require thorough investigation. Going through the jargon of sex and eroticism, it is a priori difficult to determine whether a slang term as popular as rubber 'condom' first appeared in English, Spanish, German, or some other language, but it is often presumed that the initial model was English. The same can be said for a long series of expressions like black kiss<black kiss, strict governanta<strict governess, slave $<$ slave, French < French way, and Greek<Greek love, popularized by the sexual revolution of the 1960s and 1970s - in Spain arriving with some delay because of the repression of the Franco regime. Yet, the evidence is not certain; moreover, not all expressions from this semantic field may have originated with English, even if English was one agent in their spread. Rather, English itself may have calqued foreign expressions. For example, the expression for the position sixty-nine owes its origin to Fr. soixante-neuf. First documented in the nineteenth century, ${ }^{19}$ it is believed to have spread, especially in the 1960 s, from the famous district of Pigalle (cf. Morales 2001; Rodríguez González 2011). Even more misleading can be the contrast between golden shower, for which the approximate calque lluvia dorada has been created in Spanish and the expressions golden rain and French without, which have appeared in English-language classified ads marketing sexual services, aimed at tourists frequenting the seaside resort Marbella in southern Spain. Hence these may be true Hispanisms or literal calques of the Spanish model lluvia dorada and francés sin [condón], 'golden shower' and 'fellatio without [a condom]' respectively. Another glaring example is caja tonta 'idiot box', a familiar metaphor for television which has been documented in recent decades in Spain. One could think that this is a

19 The earliest date of attestation is 1844 according to Cellard (1991) and 1878 according to Colin et al. (1990). 
creation of Spanish, perhaps attributable to Francisco Umbral who used it early on. However, 'idiot box' is already listed by the Italian lexicologist Bruno Miglorini before that, in the fifties, shortly after the popular device was introduced as a new mass medium. Also, it is known in German, the respective term being Verdummungsapparat or, more colloquial and more detached from the anglicism, Glotze, alluding to the fixed eye position and the lack of movement. (The meaning of the colloquial German verb glotzen, from which the noun derives, is roughly equivalent to the English verbs to stare and to goggle; also cf. the English compound goggle-box.)

Undoubtedly, the prior existence of a loanword in isolation (jet and set were used before the importation of jet set, show prior to the adoption of reality show) or as part of a compound (ball in football or volleyball, Sp. voleibol) facilitates the adoption and institutionalization of an anglicism. The latter example illustrates the power of analogy and the principle of linguistic economy as Sp. voleiball is gaining ground after being replaced by balonvolea in the past. Often two patterns co-occur. This situation may last for a time and lead to stylistic and sociolinguistic nuances in usage, but often the calque is coined without being preceded by an anglicism (Sp. libre comercio/Ge. Freihandel<free trade, Sp. sexo seguro/Ge. geschützter Verkehr<safe sex, Sp. microondas/Ge. Mikrowelle<microwave). In some cases, the fact that equivalence is based on translation cannot be established with complete certainty; as remarked above, it would be difficult to determine whether Sp. goma 'rubber', a colloquial term for 'condom', was first used independently or as a calque of En. rubber. The same could be said of the English adjective tax-free, Sp. libre de tasas, and Ge. steuerfrei.

Sometimes, despite the isosemantics of equivalent expressions in both languages and especially if it is old slang with the expressions showing unequal structure, it would be very risky to think of a loan influence. For instance, the sexual expressions bajarse al pilón (lit. 'to go down for the drinking trough' [fellatio]), beber de la fuente de jade (lit. 'to drink from the source of the jade' [cunnilingus]), and la viuda de los 5 dedos (lit. 'the widow of the five fingers' [masturbation]) can probably not be traced back to the English phrases to go down for someone, to dive into the $Y$, and $M r$ Thumb and his four fingers respectively. By contrast, this is possible with caja tonta, follamadres and the more recent follamigo, expressions which are direct calques of the earlier English words idiot box, motherfucker and fuckfriend (or fuckbuddy).

In some cases, similar difficulties may be connected to the etymology of socalled semantic anglicisms, because in semantic calques, often owing to common use in journalism, the English influence is generally easier to observe. If we go back to technolects or very particular sociolects such as youth language, Lázaro Carreter (1980: 244) is wrong in considering vibraciones 'vibrations' (in 
the expression 'having vibrations') as Spanish in origin as there is extralinguistic evidence that the term was inspired by an English model. Indeed, the period of the late sixties was conducive to frequent colloquialisms among young people such as to have good vibes. This truncation (also cf. the hybrid Ge. gute Vibes haben apart from the full form gute Vibrations haben) stems from the popularity of the American group The Beach Boys and, more specifically, from the title of their song 'Good Vibrations' (1968), which probably contributed to its spread (cf. Rodríguez González 2005a: 184-185).

Very rarely, a native term may lose a sense and recover it later via semantic borrowing, partly via the mechanism of interlingual homophony. This is what happened to Sp. armada<Lat. armata, which has old roots in Spanish as a synonym for 'navy', and is also sometimes employed with the meaning 'land army'. In this meaning it was used in peninsular Castilian in the fifteenth and sixteenth centuries, but subsequently lost this sense. It did not become commonplace again until the early eighteenth century when it was reborrowed from the use of Fr. armée, according to the Diccionario de Autoridades. Yet, this imposed sense was quickly obliterated again, but, interestingly, then reappeared in the twentieth century, this time via the influence of En. army, whereby the word also kept its morphological similarity with the English noun. However, current usage dictionaries do not record this use, thus showing a normative approach and suggesting that it is a misuse due to poor translations of English. In his study of anglicisms, Emilio Lorenzo (1996: 497), in line with many English textbooks, warns users about the risk of confusing the two words, despite examples which appear in the Spanish and Latin American press (also cf. Rodríguez González 2005b on this point, s.v. armada).

\subsection{Frequency of use}

Another problem area resides in the absence of comprehensive cross-linguistic work on calques, which of course was one of the motivations for embarking on this study. As a result, figures on the numbers of loans and loanshifts are scarce. Consequently, our study strove for a qualitative rather than quantitative analysis. Yet, in an impressionistic way we can make out some trends and patterns on some levels of contrastive analysis. First, it seems that contemporary Spanish is, and has always been, quite open to calquing; this impression is confirmed when reviewing dictionaries of anglicisms and foreign expressions. In this respect, the situation is not very different from other languages subject to foreign influence such as German (cf. also Busse and Görlach 2002). Second, as already suggested, the distribution of loanwords and calques generally varies according to the 
semantic field under consideration: In technical fields, and especially in certain areas such as computer technology or in some sports like golf or windsurf, lexical anglicisms dominate, unsurprisingly inasmuch as English is used as a lingua franca. But in some areas of general speech the situation is less clear. In some technolects, such as political discourse, anglicisms seem to be less wellrepresented, at least in speeches delivered in relation to the respective nation or state (cf. San Vicente 1999: 278, 280). It has also been argued that anglicisms, due to globalization, are most common in the area of economy and in select scientific fields like chemical engineering (cf. Montero-Martínez et al. 2001).

\subsection{Other challenges for cross-linguistic research}

Other challenges have to do with the fact that calques may be structurally conspicuous or not, depending on how much the respective receiving language is related to English. For instance, the modifier-head structure is habitually used for German and English compounds so that Wochenende is a masked calque on weekend. While the Spanish equivalent, fin de semana, reverses the constituent order according to an analytical pattern typical of the Romance languages. This does not apply to the term ciencia ficción. Traditionally this has been taken as an exception. In 1968 Emilio Lorenzo considered the term a clumsy calque from English science-fiction, reinforced by autochtonous creations such as politica ficción, historia ficción and archeología ficción, which proved the vitality of the neologism. He proposed the use of ficción cientifica as a preferable alternative, but the Spanish Royal Academy, in 1984, admitted ciencia ficción without mentioning its origin (cf. Lorenzo 1996: 571-572). Science fiction was first coined in English in 1851, although it was not in general use until the 1920s (cf. $B D E$ ). In French it was borrowed with the same form around 1950 (cf. Rey 2005) and through French entered in Spanish (attested in 1965 in CORDE). Indeed, some of the so-called autochtonous creations also first appeared in French (e.g. politique-fiction, histoirefiction), and very likely then entered Spanish. Now, in Spanish as in French, we cannot conclude that this represents a departure from progressive modificational tendencies generally attributed to Romance languages. According to Picone (1996: 121), it appears more likely that reanalysis has taken place such that the postposed constituent fiction takes on 'adjunct' status in the establishment of an appositional relation between the two terms. Hence they are 'co-referential' (they refer to an entity that is both 'science' and 'fiction') and therefore are in syntactic parity and not in a subordinating relation.

A further challenging point for cross-linguistic research goes back to a dissensus as to what should be part of a typology of lexical transfer. In fact, 
we should agree on a minimal degree concerning the distribution of anglicisms and calques before carrying out any comparison on an empirical basis (see also Section 2). This is a thorny issue because of a number of theoretical difficulties. Clearly enough, many of the anglicisms abounding in daily newspapers are technically speaking mere ad hoc borrowings or codeswitches, since their effects are momentary and ephemeral and therefore cannot be compared with the stability which is required for lexically enriching calques.

On the other hand, some authors also include semantic anglicisms of the paronymic type among the calques, which in principle do not seem to be very numerous. Yet, the numbers would be much higher if we also considered 'false friends' which, as noted earlier, inadvertently enter daily oral and written language. Well-known examples extracted from Prado $(1993,2001)$ are En. lecture/Sp. lectura 'reading, interpretation'; En. library/Sp. librería 'bookshop'; and En. honesty/Sp. honestidad 'decency, fairness'. The precise impact of this phenomenon is, however, difficult to calculate and evaluate. Still, if we consider calques in this very broad sense, covering all processes that various authors have studied under this label, the proportion would obviously increase (cf. Alfaro 1970 [1964]; Lorenzo 1996: 18). Anyway, even limiting ourselves to what is commonly understood by calques including semantic calques (see Section 2), the number of items to be studied is significant. There are many expressions that are translated directly, and after they have become stable lexical units or phrases, we usually do not realize any longer that they were originally based on foreign expressions, as is the case with Sp. guerra fría/Ge. Kalter Krieg < cold war, Sp. microondas/Ge. Mikrowelle<microwave, as well as the Spanish and German phrases el tiempo es oro/Zeit ist Geld<time is money.

\section{Conclusions}

Summing up, we can say that calques are a variable contact-induced phenomenon, which is determined by a complex interplay of semantic, morphological and sociolinguistic variables. They are distributed over different areas of the lexicon such as computer-related and other areas of technology, ecology, sociology, sports and politics. We have attempted to take stock of some trends and main patterns in calquing in different European languages. In so doing, we have particularly focussed on Spanish and German, underscoring both discernible differences - e.g. in the impact of calques as opposed to anglicisms - and similarities, e.g. in terms of some general mechanisms underlying the linguistic choice between an anglicism and a calque. 
As our investigation was based on dictionary data and corpus samples, there are several limitations, which may indicate potential avenues for future research. For example, more elaborate and systematic corpus analyses and an inclusion of more languages would be welcome so as to be able to verify the tendencies identified in this article. This should also include more systematic explorations of the diachronic changes that take place in different domains, either favouring anglicisms or replacive forms. Moreover, the various factors that are decisive in speakers' choices should be investigated by using refined statistical methods, applied to both written and oral data (for a recent approach see Winter-Froemel et al. 2014).

\section{References}

Adamson, Robin. 2007. The defence of French: A language in crisis? Clevedon: Multilingual Matters.

Alfaro, Ricardo. 1970 [1964]. Diccionario de anglicismos. 2nd edn. Madrid: Gredos.

Ali, Abdul Sahib Mehdi. 2005. Calquing: A means of terminological enrichment. Turjuman 14(1). 113-135.

Backus, Ad \& Margreet Dorleijn. 2009. Loan translations versus code-switching. In Barbara E. Bullock \& Almeida Jacqueline Toribio (eds.), The Cambridge handbook of linguistic codeswitching, 75-93. Cambridge: Cambridge University Press.

Bader, Yousef. 1994. Loan translations in written Jordanian news media. In Robert de Beaugrande, Abdullah Shunnaq \& Mohamed Helmy Heliel (eds.), Language, discourse and translation in the West and Middle East, 91-102. Amsterdam: Benjamins.

Balteiro, Isabel \& Miguel Ángel Campos. 2012. False anglicisms in the Spanish language of fashion and beauty. Ibérica 24. 233-260.

$B D E=$ Robert K. Barnhart (ed.). 1988. The Barnhart Dictionary of Etymology. New York: H. W. Wilson.

Betz, Werner. 1949. Deutsch und Lateinisch: Die Lehnbildungen der althochdeutschen Benediktinerregel. Bonn: Bouvier.

Busse, Ulrich \& Manfred Görlach. 2002. German. In Manfred Görlach (ed.), English in Europe, 13-36. Oxford: Oxford University Press.

Cacchiani, Silvia. 2016. On lexical Italian blends: Borrowings, hybridity, adaptations, and native word formations. In Sebastian Knospe, Alexander Onysko \& Maik Goth (eds.), Crossing languages to play with words: Multidisciplinary perspectives, 305-336. Berlin: de Gruyter.

Carstensen, Broder \& Ulrich Busse. 1993-1996. Anglizismen-Wörterbuch: Der Einfluß des Englischen auf den deutschen Wortschatz nach 1945. vol. 3. Berlin: de Gruyter.

Cellard, Jacques. 1991. Dictionnaire du français non conventionnel. Paris: Hachette.

CLAVE = Clave. 2012 [1996]. Diccionario de uso del español actual, $9^{\text {th }}$ edn. Madrid: SM.

Clyne, Michael. 2003. Dynamics of language contact: English and immigrant languages.

Cambridge: Cambridge University Press.

$C O D=$ Della Thomson (ed.). 1995. Concise Oxford dictionary of current English, 9th edn. Clarendon: Oxford.

Colin, Jean-Paul, Jean-Pierre Mével \& Christian Leclère. 1990. Dictionnaire de l'argot. Paris: Larousse. 
CORDE = Corpus diacrónico del español. Madrid: Real Academia Española. http://www.rae.es (accessed 24 March 2018).

COSMAS II= Corpus Management and Analysis System II. Mannheim: Institut für Deutsche Sprache. http://www.ids-mannheim.de/cosmas2/web-app/ (accessed 15 November 2017).

Cypionka, Marion. 1994. Französische «Pseudoanglizismen»: Lehnformationen zwischen Entlehnung, Wortbildung, Form- und Bedeutungswandel. Tübingen: Narr.

De Houwer, Annick \& Antje Wilton (eds.). 2011. English in Europe today: Sociocultural and educational perspectives. Amsterdam: Benjamins.

$D E A=$ Manfred Görlach (ed.). 2001. Dictionary of European Anglicisms. Oxford: Oxford University Press.

Dietz, Klaus. 2002. Lexikalischer Transfer und Wortbildung am Beispiel des französischen Lehngutes im Mittelenglischen. In Mechthild Habermann, Peter O. Müller \& Horst Haider Munske (eds.), Historische Wortbildung des Deutschen, 381-406. Tübingen: Niemeyer.

Dubey, Vinod. 1991. The lexical style of the Indian English newspapers. World Englishes 10(1). 19-32.

Duckworth, David. 1970. Der Einfluß des Englischen auf den deutschen Wortschatz seit 1945. Zeitschrift für deutsche Sprache 26. 9-31.

Dunger, Hermann. 1899. Wider die Engländerei in der deutschen Sprache. Zeitschrift des Allgemeinen Deutschen Sprachvereins 14. 241-251.

Dunger, Hermann. 1909. Engländerei in der deutschen Sprache. Berlin: Berggold.

Durkin, Philip. 2014. Borrowed words: A history of loanwords in English. Oxford: Oxford University Press.

Ferguson, Stuart. 1997. Language assimilation and crosslinguistic influence: A study of German exile writers. Tübingen: Narr.

Fiedler, Sabine. 2014. Gläserne Decke und Elefant im Raum. Phraseologische Anglizismen im Deutschen. Berlin: Logos.

Furiassi, Cristiano. 2010. False anglicisms in Italian. Monza: Polimetrica.

Furiassi, Cristiano \& Henrik Gottlieb (eds.). 2015. Pseudo-English: Studies on false anglicisms in Europe. Berlin: de Gruyter.

Furiassi, Cristiano, Virginia Pulcini \& Félix Rodríguez González (eds.). 2012. The Anglicization of European lexis. Amsterdam: Benjamins.

García de la Cuesta, Jorge. 2003. English-Spanish Spanish-English Aeronautical Dictionary. Madrid: Díaz de Santos.

Gómez Capuz, Juan. 1997. Towards a typological classification of linguistic borrowing (illustrated with anglicisms in Romance languages). Revista alicantina de estudios ingleses 10. 81-94.

Gómez Capuz, Juan. 2001. La interferencia pragmática del inglés sobre el español en doblajes, telecomedias y lenguaje coloquial: Una aportación al estudio del cambio lingüístico en curso. Tonos Digital 2.

Gómez Capuz, Juan. 2005. La inmigración léxica. Madrid: Arco/Libros.

Görlach, Manfred (ed.). 2002. English in Europe. Oxford: Oxford University Press.

Görlach, Manfred. 2003. English words abroad. Amsterdam: Benjamins.

Gottlieb, Henrik. 2004. Danish echoes of English. Nordic Journal of English Studies 3(2). 39-65.

Gottlieb, Henrik. 2005. Anglicisms and translation. In Gunilla M. Anderman \& Margaret Rogers

(eds.), In and out of English: For better, for worse? 161-184. Clevedon: Multilingual Matters.

Haugen, Einar I. 1950. The analysis of linguistic borrowing. Language 26. 210-231.

Hoffmann, Charlotte. 1996. Societal and individual bilingualism with English in Europe. In Reinhard R. K. Hartmann (ed.), The English language in Europe, 47-60. Oxford: Intellect. 
Humbley, John. 2008. Emprunts, vrais et faux, dans le Petit Robert 2007. In Jean Pruvost (ed.), Dictionnaires et mots voyageurs: Les 40 ans du petit Robert, de Paul Robert à Alain Rey, 221-238. Éragny-sur-Oise: Éd. des Silves.

Jansen, Silke. 2005. Sprachliches Lehngut im world wide web: Neologismen in der französischen und spanischen Internetterminologie. Tübingen: Niemeyer.

Johanson, Lars. 2002. Structural factors in Turkic language contacts. Richmond: Curzon. Knospe, Sebastian. 2014. Entlehnung oder Codeswitching? Sprachmischungen mit dem Englischen im deutschen Printjournalismus. Frankfurt: Peter Lang.

Koll-Stobbe, Amei. 2005. Forever young? Sprachliche Kodierungen von Jugend und Alter. In Heike Hartung (ed.), Alter und Geschlecht: Repräsentationen, Geschichten und Theorien des Alter(n)s, 237-252. Bielefeld: Transcript.

Lázaro Carreter, Fernando. 1980. Estudios de Lingüística. Barcelona: Crítica.

Leisi, Ernst \& Christian Mair. 2008. Das heutige Englisch: Wesenszüge und Probleme. Heidelberg: Winter.

Linn, Andrew, Neil Bermel \& Gibson Ferguson (eds.). 2015. Attitudes towards English in Europe, vol. 1: English in Europe. Berlin: de Gruyter.

Lipski, John M. 2008. Varieties of Spanish in the United States. Georgetown: Georgetown University Press.

Lorenzo, Emilio. 1996. Anglicismos hispánicos. Madrid: Gredos.

Lutz, Angelika. 2002. Sprachmischung in der deutschen und englischen Wortbildung. In Mechthild Habermann, Peter O. Müller \& Horst Haider Munske (eds.), Historische Wortbildung des Deutschen, 407-438. Tübingen: Niemeyer.

Madariaga, Salvador de. 1962. El español, colonia lingüística del inglés. Cuadernos del Congreso por la libertad de la cultura 59. 45-49.

Madariaga, Salvador de. 1966. ¿Vamos a Kahlahtahyood? Revista de Occidente 36. 365-373.

Mailhammer, Robert. 2008. The wolf in sheep's clothing: Camouflaged borrowing in Modern German. Folia Linguistica 42(1-2). 177-193.

Matras, Yaron. 2009. Language contact. Cambridge: Cambridge University Press.

Matras, Yaron \& Jeannette Sakel. 2007. Investigating the mechanisms of pattern-replication in language convergence. Studies in Language 31. 829-865.

Matthisson, Friedrich von. 1825 [1793]. Schriften, vol. 3. Zürich: Drell, Füßli und Compagnie.

Meriläinen, Lea, Helka Riionheimo, Päivi Kuusi \& Hanna Lantto. 2016. Loan translations as a language contact phenomenon: Crossing the boundaries between contact linguistics, second language acquisition research and translation studies. Philologia Estonica Tallinnensis 1. 104-124.

Moliner, María. 2007 [1998]. Diccionario de uso del español. 3rd edn. Madrid: Gredos.

Montero-Martínez, S., Pedro A. Fuertes-Olivera \& M. García de Quesada. 2001. The translator as 'language planner': Syntactic calquing in an English-Spanish technical translation of chemical engineering. Meta 46(4). 687-698.

Morales, Gregorio 2001. Historia del 69. Quo, June, 51-52. https://www.quo.es/ser-humano/ a30424/historia-del-69-50799/.

Muhr, Rudolf. 2002. Anglizismen als Problem der Linguistik und Sprachpflege in Österreich und Deutschland zu Beginn des 21. Jahrhunderts. In Rudolf Muhr \& Bernhard Kettemann (eds.), Eurospeak: Der Einfluss des Englischen auf europäische Sprachen zur Jahrtausendwende, 9-54. Frankfurt: Peter Lang.

Munske, Horst Haider \& Alan Kirkness (eds.). 1996. Eurolatein: Das griechische und lateinische Erbe in den europäischen Sprachen. Tübingen: Niemeyer. 
Myers-Scotton, Carol. 1995. Social motivations for code-switching: Evidence from Africa. Oxford: Clarendon.

Nefedova, Lyubov \& Oleg Polyakov. 2014. On some aspects of borrowing of phrases from English into German and Russian. In Elena Arsenteva (ed.), Phraseology in multilingual society, 141-155. Newcastle: Cambridge Scholars.

OED = Oxford English Dictionary online. http://www.oed.com.

Onysko, Alexander. 2007. Anglicisms in German: Borrowing, lexical productivity, and written codeswitching. Berlin: de Gruyter.

$T N P D=$ Eric Partridge, Tom Dalzell \& Terry Victor (eds.). 2006. The new Partridge dictionary of slang and unconventional English, 9th edn. New York: Routledge.

Pfalzgraf, Falco. 2009. Linguistic purism in the history of German. In Geraldine Horan, Nils Langer \& Sheila Watts (eds.), Landmarks in the history of the German language, 137-168. Frankfurt: Peter Lang.

Picone, Michael D. 1996. Anglicisms: Neologisms and dynamic French. Amsterdam: Benjamins. Prado, Marcial. 1993. NTC's dictionary of Spanish false cognates. Lincolnwood, IL: National Textbook Company.

Prado, Marcial. 2001. Diccionario de falsos amigos inglés-español. Madrid: Gredos.

Pratt, Chris. 1980. El anglicismo en el español peninsular contemporáneo. Madrid: Gredos.

Pütz, Martin \& JoAnn Neff-Van Aertselaer (eds.). 2008. Developing contrastive pragmatics: Interlanguage and cross-cultural perspectives. Berlin: de Gruyter.

Rash, Felicity J. 1994. Amerikanismen in der deutschen Sprache der Schweiz - Ein Zwischenbericht. Sprachspiegel 50(6). 2-11.

Rey, Alain. 2005. Dictionnaire culturel en langue française. Paris: Le Robert.

Rheinische Post Online. 2010. So bekämpft Ramsauer Anglizismen. https://rp-online.de/poli tik/deutschland/so-bekaempft-ramsauer-anglizismen_iid-23667387 (accessed 15 January 2017).

Rodríguez González, Félix. 1988. The proliferation and use of acronym derivatives: Conditioning factors. Cahiers de lexicologie 1. 65-82.

Rodríguez González, Félix. 1991. Translation and borrowing of acronyms: Main trends. International Review of Applied Linguistics 29(2). 161-170.

Rodríguez González, Félix. 1996. Functions of anglicisms in contemporary Spanish. Cahiers de lexicologie 68(1). 107-128.

Rodríguez González, Félix. 2002a. Spanish. In Manfred Görlach (ed.), English in Europe, 128-150. Oxford: Oxford University Press.

Rodríguez González, Félix. 2002b. Anglicismos y calcos en español actual. In Félix San Vicente (ed.), L'inglese e le altre lingue europee. Studie sull'interferenza lingüística, 149-169. Bolonia: CLUEB.

Rodríguez González, Félix. 2005a. Calcos y traducciones del inglés en español actual. In Pedro Fuertes (ed.), Lengua y sociedad: Aportaciones recientes en lingüística cognitiva, lenguas en contacto, lenguajes de especialidad y lingüística del corpus, 177-192. Valladolid: Universidad de Valladolid.

Rodríguez González, Félix. 2005b. Diccionario de terminología y argot militar: Vocabulario del soldado y la vida del cuartel. Madrid: Verbum.

Rodríguez González, Félix. 2008. Anglicisms in Spanish male homosexual terminology. In Roswitha Fischer \& Hanna Pułaczewska (eds.), Anglicisms in Europe: Linguistic diversity in a global context, 247-272. Newcastle: Cambridge Scholars.

Rodríguez González, Félix. 2011. Diccionario del sexo y del erotismo. Madrid: Alianza Editorial. 
Rodríguez González, Félix. 2013. Pseudoanglicismos en español actual. Revisión crítica y tratamiento lexicográfico. Revista Española de Lingüística 43(1). 123-169.

$G D A=$ Rodríguez González, Félix. 2017. Gran diccionario de anglicismos. Madrid: Arco/Libros.

San Vicente, Félix. 1999. Actualidad del lenguaje político. In María Vittoria Calvia \& Félix San Vicente (eds.), La identidad del español y su didáctica, vol. 2, 97-127. Viareggio: Baroni. Sánchez Fajardo, José Antonio. 2016. Anglicisms in Cuban Spanish. Alicante: Universidad de Alicante dissertation.

Sánchez Fajardo, José Antonio. 2017. A dictionary of 1,000 English loanwords in Cuban Spanish with usages, synonyms, and etymologies. New York: Edwin Mellen.

Santoyo, Julio César. 1988. Los calcos como forma de traducción. Problemas de la traducción, 91-97. Madrid: Fundación Alfonso X el Sabio.

Seco, Manuel. 1977. El léxico de hoy. In Rafael Lapesa (ed.), Comunicación y lenguaje, 183-201. Madrid: Karpos.

Seco, Manuel, Olimpia Andrés \& Gabino Ramos. 2011 [1999]. Diccionario del español actual. 2nd edn. Madrid: Aguilar.

Thomason, Sarah G. 2001. Language contact: An introduction. Edinburgh: Edinburgh University Press.

$T L F=$ Trésor de la langue française: Dictionnaire de la langue française du xviii ${ }^{e}$ et du $x x^{e}$ siècle (1789-1960). 1977. Paris: CNRS.

Tóth, Gegerly. 2007. Linguistic interference and first-language attrition: German and Hungarian in the San Franciso Bay area. New York: Peter Lang.

Verein Deutsche Sprache. 2016. Der Anglizismen-INDEX. https://www.vds-ev.de/aindex/ suche2.php (accessed 15 January 2017).

VOX = Diccionario general de la lengua española. 2009 [2006]. 2nd edn. Barcelona: Larousse. Weinreich, Uriel. 1953. Languages in contact: Findings and problems. The Hague: Mouton.

Winford, Donald. 2003. An introduction to contact linguistics. Malden, MA: Blackwell.

Winter-Froemel, Esme. 2008. Unpleasant, unnecessary, unintelligible? Cognitive and communicative criteria for judging borrowings and alternative strategies. In Roswitha Fischer \& Hanna Putaczewska (eds.), Anglicisms in Europe: Linguistic diversity in a global context, 16-41. Newcastle: Cambridge Scholars.

Winter-Froemel, Esme. 2011. Entlehnung in der Kommunikation und im Sprachwandel - Theorie und Analysen zum Französischen. Berlin: de Gruyter.

Winter-Froemel, Esme, Alexander Onysko \& Andreea Calude. 2014. Why some non-catachrestic borrowings are more successful than others: A case study of English loans in German. In Amei Koll-Stobbe \& Sebastian Knospe (eds.), Language contact around the globe:

Proceedings of the LCTG3 conference, 119-142. Frankfurt: Peter Lang. 